Pace University

DigitalCommons@Pace

2012

\title{
Managing Climate Change through Biological Sequestration: Open Space Law Redux
}

John R. Nolon

Elisabeth Haub School of Law at Pace University

Follow this and additional works at: https://digitalcommons.pace.edu/lawfaculty

Part of the Environmental Law Commons, and the Land Use Law Commons

\section{Recommended Citation}

John R. Nolon, Managing Climate Change through Biological Sequestration: Open Space Law Redux, 31 Stan. Envtl. L. Rev. 195 (2012), http://digitalcommons.pace.edu/lawfaculty/784/.

This Article is brought to you for free and open access by the School of Law at DigitalCommons@Pace. It has been accepted for inclusion in Pace Law Faculty Publications by an authorized administrator of DigitalCommons@Pace. For more information, please contact dheller2@law.pace.edu. 


\title{
Managing Climate Change Through Biological Sequestration: Open Space Law Redux
}

\author{
John R. Nolon*
}

I. Recalibrating Open SPace LaW to Manage Climate

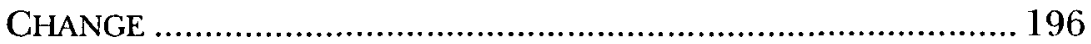

A. The Green Edge of the Wedge.................................. 196

B. A New Focus for Climate Change Policy ....................... 197

C. Bringing Open Space Law to Scale ............................ 201

II. The Gathering Consensus Regarding Climate Change

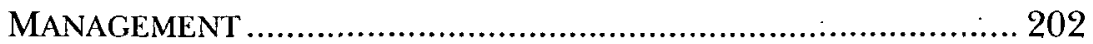

III. The SequeStration Strategy: TARgeting The LandS That

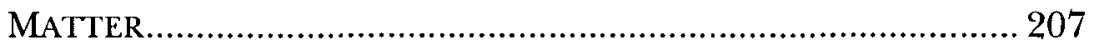

IV. OPEN SPACE LAW: STATE AND Local ORIGINS ...................... 210

A. Using Open Space Law to Accomplish Sequestration .... 210

B. Legality of Local Sequestration Laws ......................... 214

C. State Financing of Open Space Acquisition.................. 219

V. LOCAL LAND USE LAWS AND PROGRAMS THAT ENHANCE SEQUESTRATION ......................................................... 222

A. Regulatory Approaches ......................................... 223

1. Planning and Zoning ....................................... 223

2. Site Plan and Subdivision Regulations .................. 225

3. Supplemental Regulations.............................. 230

* John R. Nolon is the James D. Hopkins Professor of Law at Pace Law School, Visiting Professor at the Yale School of Forestry and Environmental Studies, and Counsel to the Pace Land Use Law Center. He is grateful for the tireless efforts of his research assistant, Joe Fornadel, and for the valuable insights provided by the professors participating in the 2011 Colloquium on Environmental Scholarship at Vermont Law School, where this paper was first presented. 
B. Land Acquisition ................................................. 238

1. Local Financing Sources..................................... 240

2. .Purchase of Development Rights ........................ 241

3. Conservation Easements ..................................... 242

4. Working with Land Trusts .................................... 243

VI. OPEN SPACE LAW REVISITED: TOWARD A NATIONAL BIOLOGICAL

SEQUESTRATION STRATEGY.................................................. 245

A. Measurements.................................................... 246

B. Strategies ........................................................... 247

C. Incentives ........................................................ 247

\section{Recalibrating Open Space Law to Manage Climate Change ${ }^{1}$}

\section{A. The Green Edge of the Wedge}

Dr. Robert Socolow, a professor of engineering at Princeton University, suggests that we attack climate change by utilizing every strategy available under current technologies. He organizes actions into "stabilization wedges," each one capable of having significant positive effect over time. ${ }^{2}$ This Article proposes a national biological sequestration policy: the green edge of a land use stabilization wedge. This policy will reduce carbon dioxide in the atmosphere by increasing the amount of emissions that are sequestered by the natural environment and enable human settlements to adapt to the harsh effects of a changing climate, while realizing a number of other benefits that preserved open space achieves. ${ }^{3}$

1. This Article is one of four that examine how local land use law can be used as an effective strategy to manage climate change. See John R. Nolon, The Land Use Stabilizalion Wedge Strategy: Shifting Gound to Mitigate Climate-Change, 34 WM. \& MARY ENVTL. L. \& POL’Y REV. 1 (2009) [hereinafter Land Use Stabilization Wedge Strategy]; John R. Nolon, Land Use for Energy Conservation: A Local Strategy for Climate Change Mitigation, 27 J. LAND USE \& ENVTL. L. (forthcoming Spring 2012); John R. Nolon, Regulatmy Takings and Property Rights Confront Sea Level Rise: How Do They Roll, 21WIDENER L. REV. (forthcoming 2012).

2. Socolow identifies and describes fifteen categories for organizing society's efforts to address climate change. Stephen Pacala \& Robert Socolow, Siabilization Wedges: Solving the Climate Problem for the Next 50 Years with Current Technologies, 305 ScI. 968 (2004). Five of his categories fall within the reach of local land use authority: reduced use of vehicles, energy efficient buildings and appliances, vegetative carbon sequestration, wind power, and solar power. See id. at 970.

3. See The Land Use Stabilization Wedge Strategy, supra note 1, at 21-26 (describing various land use actions that state and local governments can take to manage climate change, including mixed use development, improved energy conservation codes, 
Biological sequestration of $\mathrm{CO}_{2}$ emissions occurs within the vegetated environment-places like forests, pastures, meadows, and crop lands. These landscapes naturally absorb and store carbon. According to the most recent EPA estimates, biological sequestration currently offsets approximately eighteen percent of total domestic $\mathrm{CO}_{2}$ emissions. ${ }^{4}$ Most biological sequestration is due to carbon uptake and storage by forestlands, with pastures, meadows, cropland, and urban forests contributing as well. ${ }^{5}$

The Article sketches the influences of international and national climate change law, which largely ignore the benefits of biological sequestration on privately owned land in developed countries. It then turns to an analysis of climate change and its consequences, before exploring how mitigation and adaptation can be accomplished by preserving and enhancing the natural landscape in both rural and urban areas. Open Space Law presents policy makers with readily available tools to protect the sequestering environment: the natural and man-made landscapes that capture and store carbon organically and provide ecosystem resiliency.

This body of law has emerged spontaneously over the past few decades, responding to countless local perturbations, largely unaided by cogent federal strategies. The local and state initiatives that have evolved to preserve and enhance open space provide the basis for a broader sequestration policy, one that builds on available legal technology and existing norms to respond to the looming global perturbation of climate change.

\section{B. A New Focus for Climate Change Policy}

Much of the emphasis in climate change policy is on legal mechanisms that cap greenhouse gas (GHG) emissions, tax carbon, establish trading markets, require cleaner energy in fuels,

preservation of carbon sinks, green energy sources, and promotion of transit oriented development.(TOD) and transportation efficient development (TED) in zoning and planning).

4. U.S. EPA, INVENTORY OF U.S. GREENHOUSE GAS EMISSIONS AND SINKS: 1990-2009, at ES-13 (2011) [hereinafter EPA GREENHOUSE GAS INVENTORY].

5. Id. (863.1 teragrams ( $\mathrm{Tg}$ ) of $\mathrm{CO}_{2}$ equivalent (eq.) attributed to forest land out of a total of 1015.1 Tg $\mathrm{CO}_{2}$ eq. sequestered by all United States carbon sinks). Given the statistics presented in this report, the following strategies are important to the United States' current biological sequestration portfolio: forest land remaining forest land; cropland remaining cropland; grassland remaining grassland; and converting land to grassland. See id. 
reduce energy consumption, or produce alternative fuel and vehicles. ${ }^{6}$ The focus of these policies is often on international conventions or accords such as those framed in Kyoto and Copenhagen and, in the United States, on federal and state laws that concentrate on power plant emissions, energy policy, alternative fuels, and fuel-efficient vehicles. This field of study has become known as climate change law. The preservation of private lands that sequester carbon in developing countries is a peripheral concern of this body of law.

Sustainable development law, which includes the preservation of open space, focuses on shaping land and economic development to have a lighter impact on the environment, including, but not limited to, climate change mitigation and adaptation. Sustainable development law encourages human settlement patterns and building practices that use less material, preserve existing open space, avoid consuming wetlands or eroding watersheds, use less energy, emit less $\mathrm{CO}_{2}$, lessen stormwater runoff, reduce ground and surface water pollution, and create healthier places for living, working, and recreating. This body of law is created mainly by state and local governments, which have the principal legal authority to regulate building construction, land use, and the conservation of natural resources at the local level. ${ }^{7}$

In the $1980 \mathrm{~s}$, when the concept of sustainability attained currency at the international level, it embodied both the forces of economic development and environmental protection and explicitly included climate change mitigation. In 1983, the Secretary-General of the United Nations (U.N.) tapped Gro Harlem Brundtland, Prime Minister of Norway, to chair the independent World Commission on the Environment and Development, which had just been created by the U.N. General

6. See generally Global Climate Change and U.S. Law (Michael B. Gerrard ed., 2007) (including chapters on "The International Regime [of Climate Change Law]," "The Impact of the Kyoto Protocol on U.S. Business," "Subsidies, Tax Policy, and Technological Innovation," and "Emissions Trading-Practical Aspects"); RICHARD G. Hildreth ET al., Climate Change LaW: Mitigation and adaptation (2009) (containing similar chapters); CHRIS WOLD ET AL., ClimATE CHANGE AND THE LAW (2009) (containing similar chapters).

7. See John R. Nolon, Historical Overview of the American Land Use System: A Diagnostic Approach to Exaluating Government Land Use Control, in LAND USE LAW FOR SUSTAINABLE DEVELOPMENT: A DLAGNOSTIC APPROACH TO EVALUATING GOVERNMENT LAND USE CONTROL 581, 587-90 (Nathalie J. Chalifour et al. eds., 2007). 
Assembly. ${ }^{8}$ Following World War II, economic development was unfriendly to environmental interests and left the poor behind. The Brundtland Commission's task was to address this problem.

In 1987, the Commission issued its report entitled Our Common Future, sometimes referred to as the Brundtland Commission Report. ${ }^{9}$ It defined sustainable development as "a process of change ... [that] enhance[s] both current and future potential to meet human needs and aspirations." 10 The Commission noted that "there has been a growing realization in national governments and multilateral institutions that it is impossible to separate economic development issues from environmental issues; many forms of development erode the environmental resources upon which they must be based, and environmental degradation can undermine economic development." 11

Conferences of the Parties to the United Nations Framework Convention on Climate Change ${ }^{12}$ have resulted in general agreements to mitigate land use and land cover changes that are responsible for releasing GHGs to the atmosphere through the disturbance of soils and deforestation, particularly when it is followed by agriculture. ${ }^{13} \mathrm{~A}$ variety of multilateral agreements and forums on the environment have considered how to deal with climate change mitigation through sequestration. ${ }^{14}$ Little of this

8. REPORT OF THE WORLD COMMISSION ON ENVIRONMENT AND DEVELOPMENT: OUR COMmon FUTURE, Chairman's Foreword, U.N. Doc. Annex to A/42/427 (Aug. 4, 1987), available at http:/ / www.un-documents.net/wced-ocf.htm.

9. Id.

10. Id. at Ch. $2 \llbracket 15$.

11. Id. at "From One Earth to One World" 18.

12. Essential Background, United NATIONS Framework CONVENTION ON Climate CHANGE, http://unfccc.int/essential_background/items/2877.php (last visited Mar. 3, 2012).

13. Report of the Conference of the Parties. 13th Sess. [COP-13], Bali Action Plan, 3, U.N. Doc. FCCC/CP/2007/6/Add.1 (Mar. 14, 2008) [hereinafter Bali Conference Report]; Kyoto Protocol to the United Nations Framework Convention on Climate Change, Dec. 10, 1997, 37 I.L.M. 22, 33 [hereinafter Kyoto Protocol].

14. These include the Conference of the Parties agreement in Bonn, the United Nations Convention to Combat Desertification, the United Nations Convention on Biological Diversity, the Ramsar Convention of Wetlands, and the Bali Action Plan. Under the Kyoto Protocol, the parties considered various methods of promoting forest conservation practices in the interest of mitigation. See, e.g., Kyoto Protocol, art. II(I)(a)(ii). The Kyoto Protocol nominally incorporated sequestration practices in calculating net emission reductions in developed countries and standards for creating tradable certified emission reduction credits in developing countries, but very little progress in defining and approving such measures has occurred. See id. art. II(1)(a)(iv). The Intergovernmental Forum on Forests has dedicated attention to a broad range of 


\section{international activity has informed or influenced biological sequestration policy in the United States. Federal policies focus mainly on the management of public lands. ${ }^{15}$ There are over 650}

issues relating to sustainable forest management. See Comm. on Sustainable Dev., Intergovernmental Forum on Forests, Rep. on its Fourth Session, Jan. 31-Feb. 11, 2000, U.N. Doc. E/CN.17/2000/14 (Mar. 20, 2000). The purpose of the Bonn Agreement was to lay a foundation for developing nations to establish land use practices that qualify as credits toward meeting assigned carbon reduction targets. The agreement focused rather narrowly on forest credit creation under the rubric Reducing Emissions from Deforestation and Degradation. See Conference of the Parties, Rep. on the Second part of Its Sixth Session, July 16-17, 2001, U.N. Doc. FCCC/CP/2001/5/Add.1 (Sept. 25, 2001). The Bali Action Plan requires the parties to create an instrument that provides for forestbased mitigation in developing countries, including financial incentives. The parties in Bali also committed to reduce emissions from deforestation in developing countries, including the transfer of technology for forest preservation from developed to developing countries. Bali Conference Report, supra note 13, at 8-10.

15. During most of the nineteenth century, the federal government sold federal land, including heavily forested areas, to settlers to encourage the westward movement of the nation's population. Timber was harvested for fuel, building materials, railroads, or to make room for farming or ranching. Much of the harvested land was clear cut and not replanted. The result was significant erosion, fires, and the invasion of lands by foreign species. See Reserve Act and Congress: Passage of the 1891 Act, U.S. FOREST SERV., http://www. foresthistory.org/ASPNET/Publications/centennial_minis/chapl2.htm (last visited Mar. 19, 2008). The Forest Reserve Act of 1891 authorized the President to reserve forest lands and put them under public management. Id. Through The Forest Management Act of 1897, federal law defined the purpose of federal reserves to include forest preservation, watershed protection, as well as a source of timber supply for the nation. See Forest Reserves and Forest Rangers, U.S. FOREST SERV., http://www.foresthistory.org/ASPNET/ Publications/centennial_minis/chap13.htm (last visited Mar. 19, 2008). In the early part of the twentieth century, the focus regarding these federal lands was on managing a sustainable supply of lumber for the country's wood and paper industries. $I d$. By the end of the century, national forest policy had become more attuned to the nontimber value of forests, including water quality protection, prevention of erosion, preservation of biodiversity, and recreation. See Conserzalion and Forest Products, U.S. FOREST SERV., http://www.foresthistory.org/ASPNET/Publications/centennial_minis /chap20.htm (last visited Mar. 19, 2008). Under the National Forest Management Act of 1976, Congress authorized the conduct of scientific research to protect the nation's renewable resources noting that deforestation threatens the global environment. National Forest Management Act of 1976, sec. 4, Pub. L. No. 94-588, 90 Stat. 2949 (1976) (codified as amended at 16 U.S.C. $\$ 1601(d)(1))$. The Federal Land Policy and Management Act of 1976 authorizes the Secretary of the Interior to issue regulations to protect public lands of critical environmental concern. Federal Land Policy and Management Act of 1976, sec. 201, Pub. L. No. 94-579, 90 Stat. 2743 (1976) (codified as amended at 43 U.S.C. $\$ 1711$ ). According to the National Wildlife Refuge System Improvement. Act of 1997, the Fish and Wildlife Service can permit only uses of land under its management that are compatible with the preservation of habitat and wildlife. National Wildlife Refuge System Improvement Act of 1997, sec. 6, § 3(A) (i), Pub. L. No. 105-57, 111 Stat. 1252 (1997) (codified as amend at 16 U.S.C. $\$ 668 \mathrm{dd})$. By the turn of the last century, there was evidence that federal forest policy recognized carbon sequestration as a relevant objective. See Linda S. Heath \& Linda A. Joyce, Carbon Sequestration in Forests as a National Policy Issue, in COMMUNICATING THE Role of Silviculture IN MANaGing THE NATIONAL Forests 29, $29-30$ (U.S. Dep't of 
million acres in federal preserves today, managed by four separate federal agencies.

Most of the forested lands, pasture, meadows, cropland, and urban trees in the United States are privately owned. As noted, the private use of this land is regulated primarily by state and local law. ${ }^{16}$ State and local governments have taken a variety of approaches toward protecting environmental resources that can be used to protect forests and the vast acreages of privately owned land that are heavily vegetated and sequester carbon.

\section{Bringing Open Space Law to Scale}

This Article places state and local initiatives that protect undeveloped land and vegetated landscapes under the rubric of Open Space Law. These laws embody a large number of environmental objectives that can be accomplished by preserving open space resources and functions. ${ }^{17}$ Under express or implied legal authority delegated by their state legislatures, local governments have adopted a variety of laws that involve open space protection or management. These include environmentally sensitive area designation; erosion and sedimentation control; standards for grading, filling, drainage, soil disturbance, and removal of vegetation; floodplains control; natural resource management; watershed, groundwater, watercourse, and wetland protection; landscaping requirements; ridgeline, steep slope, scenic resource, and shoreline regulation; stormwater management; timber harvesting regulations; tree protection and canopy expansion; and the transfer of development rights from lands to be preserved to developable areas. ${ }^{18}$

Agric. ed., 1997). Today 657 million acres of land are in federal reserves; they are managed by four federal agencies including the National Park Service, the Fish and Wildlife Service, the Bureau of Land Management, and the Forest Service. The BLM: Yesterday and Today, BUREAU OF LAND MGMT., http://www.blm.gov/ca/st/en/info/about _blm/history.print.html (last visited Mar. 27, 2012).

16. See Nolon, supra note 7 , at 587-90.

17. See Janice C. Griffith, Green Infrastructure: The Imperative of Open Space Preservation, 42 URB. LAW. 259 (Fall 2010/Winter 2011) (presenting the preservation of open space as an imperative necessitated by land development accompanying urban sprawl). "Green space protection helps to achieve sustainability by foreclosing the energy demands and carbon emissions that occur with land development." Id. at 268. "Only a few Americans are aware that the United States loses open space at a rate of 6,000 [acres] each day-4 acres per minute." Id. at 274 .

18. John R. Nolon, In Praise of Parochialism: The Advent of Local Environmental Law, in New Ground: The Advent of LoCal ENVIRonmental LaW 3, 10 (John R. Nolon ed., 
Most local environmental laws and open space protections of this type are enacted because of perturbations at the community level: the loss of a treasured viewshed, the gradual decline of visible open space, surface water or groundwater pollution, increased flooding, or the disappearance of treasured wildlife, among others. It is because the evidence of climate change and environmental degradation on the ground is first observed and of greatest concern to local stakeholders that open space law must retain a local dimension. ${ }^{19}$ The need, however, is to bring these local efforts to scale, particularly when the objective is to achieve a goal as ambitious as climate change mitigation and adaptation. This Article explores the growing consensus regarding the threat of climate change, the importance of open space preservation as a management strategy, the local and state origins of this body of law, and the techniques for open space enhancement that have evolved, and concludes with a discussion of how federal policies can organize and reshape Open Space Law to become a powerful national biological sequestration initiative.

\section{The Gathering Consensus Regarding Climate Change MANAGEMENT}

The changes on the ground that are attributable to climate change are increasingly obvious. The 2009 report of the U.S. Global Change Research Program pinpoints the following observable or projected domestic results of climate change: ${ }^{20}$

- increased air and water temperatures;

- increased degradation of fresh-water fish habitat;

- diminished terrestrial biodiversity;

- increased bleaching and die-off of coral reefs;

- increased frequency and intensity of heavy downpours;

2003).

19. Jamie Williams, Scaling up Conservation for Large Landscapes, LAND LiNES, July 2011 , at 8,13 ("Local people are moved to act by the power of their own place and in their own way. Designing strategies at a large scale is often too abstract for landowners at best, or outright alienating at worst. As in politics, all conservation is local.").

20. U.S. Global Change Research Program, Global Climate Change Impacts in THE UNITED STATES 9 (Thomas R. Karl et al. eds., 2009) [hereinafter Global Climate ChANGE IMPACTS IN THE U.S.]. The U.S. Global Change Research Program was charged with the responsibility of preparing this report by the Global Change Research Act of 1990, Pub. L. No. 101-606, 104 Stat. 3096 (1990) (codified at 15 U.S.C. $§ 2921$ ). See Program Overview, U.S. GLOBAL CHANGE RESEARCH PROGRAM, http://www.globalchange.gov/about (last visited Mar. 3, 2012). 
- a rise in sea level;

- reduced snow cover, glaciers, permafrost, and sea ice;

- reduced water supply in some regions;

- lengthened ice-free periods on lakes and rivers;

- lengthened growing seasons; and

- increased water vapor in the atmosphere. ${ }^{21}$

The report also lists likely future changes including drier conditions in some regions and more intense hurricanes with related increases in wind, rain, and storm surges. ${ }^{22}$ These changes, it reports, will affect human health, ${ }^{23}$ water supply, ${ }^{24}$ agriculture, ${ }^{25}$ coastal areas, ${ }^{26}$ and many other aspects of society and the natural environment. ${ }^{27}$

The Intergovernmental Panel on Climate Change (IPCC) released its Fourth Assessment Report in 2007. ${ }^{28}$ The report found that over the last fifty years global average surface temperature has risen, global average sea level has risen, and snow cover in both hemispheres has decreased. ${ }^{29}$ These changes are "very likely due to the observed increase in anthropogenic GHG concentrations," as global GHG emissions have risen " $70 \%$ between 1970 and 2004." ${ }^{30} \mathrm{CO}_{2}$ specifically composed seventy-seven percent of total

21. GlOBAL Climate ChANGE IMPACTS IN THE U.S., supra note 20 , at 27.
22. Id. at $32-36$.
23. Id. at 89.
24. Id. at 41 .
25. Id. at 71.
26. Id. at 84.
27. Id. at 99 .
28. IPCC, ClimATE CHANGE 2007: SYNTHESIS REPORT (2007) [hereinafter IPCC SYNTHESIS REPORT], available at http://www.ipcc.ch/pdf/assessmentreport/ar4/syr/ ar4_syr.pdf. See also JOHn R. NOLON \& PATricia E. Salkin, Climate Change AND SuSTAINABLE DEVELOPMENT LAW IN A NuTSHELl 23-24 (2011) ("Over 40 writing teams and 450 lead authors - selected as lead authors because of their expertise - contributed to the Fourth Assessment Report. The report contains over 18,000 citations to scientific reports, the majority of which were published in peer-review journals. The lead authors were assisted by over 800 scientists and analysts who participated as contributing authors on specific topics. These authors contributed their time and were assisted by four Technical Support Units with paid staff.").

29. IPCC, SYNTHESIS REPORT, supra note 28 , at 30 . The IPCC found that "[t] he linear warming trend over the 50 years from 1956 to $2005\left(0.13[0.10 \text { to } 0.16]^{\circ} \mathrm{C}\right.$ per decade) is nearly twice that for the 100 years from 1906 to 2005." Id. Additionally, "[i]ncreases in sea level are consistent with warming ... [as g]lobal average sea level rose at an average rate of 1.8 [1.3 to 2.3$] \mathrm{mm}$ per year over 1961 to 2003 and at an average rate of about 3.1 [2.4 to $3.8 \mathrm{~mm}$ per year from 1993 to 2003 ." $I d$.

30. Id. at 36 . 
anthropogenic greenhouse gas emissions in 2004, resulting in thirty-eight gigatons $(\mathrm{Gt})$ of $\mathrm{CO}_{2}$ being released into the atmosphere. ${ }^{31}$ Such gases

are denominated "greenhouse" gases because the sun's rays pass through them but they inhibit the escape of heat. This causes the atmosphere to warm and global temperatures to rise. As we burn more fossil fuel to heat and cool buildings, run appliances, and drive personal vehicles across the landscape, we increase the concentration of $\mathrm{CO}_{2}$ and accentuate this greenhouse effect. ${ }^{32}$

The IPCC's Special Report on Emissions Scenarios estimates that without changes in policies and practices that could mitigate GHG emissions an increase of global GHG emissions by twenty-five to ninety percent $\left(\mathrm{CO}_{2}\right.$-eq) between 2000 and 2030 will occur. ${ }^{33}$ Consistent with such an increase, "[c]ontinued GHG emissions at or above current rates would cause further warming and induce many changes in the global climate system during the twenty-first century that would very likely be larger than those observed during the twentieth century." 34

The consequences of climate change are further confirmed and made even more vivid by America's Climate Choices, the 2011 report of the National Academy of Sciences. ${ }^{35}$ This study of climate change and greenhouse gases was undertaken pursuant to an act of Congress. ${ }^{36}$ The report confirms that the Earth's average surface

31. Id. (stating $38 \mathrm{Gt}$ is the IPCC's most recent measurement of global $\mathrm{CO}_{2}$ emissions in a single year).

32. NOLON \& SALKIN, supra note 28 , at 24.

33. IPCC SYNTHESIS REPORT, supra note 28, at 44.

34. Id. at 45 .

35. Comm. ON America's Climate Cholces, Nat'l ACAd. OF Sci., America's Climate Choices 15-27 (2011).

36. Id. at vii. The Consolidated Appropriations Act, 2008, Pub. L. No. 110-161, \$114, 83 Stat. 144 (2007), specifies that money provided to the National Oceanic and Atmospheric Administration, Operations, Research and Facilities shall be used to establish the Climate Change Study Committee in conjunction with the National Academy of Sciences, part of the National Academies. The Act requires that the National Academy of Sciences shall host a Summit on Global Climate Change. In addition, the Act requires the Climate Change Study Committee to issue a report within two years after the date the committee convenes. Under section 114, the National Academy of the Sciences directed the National Research Council to organize a Summit on Global Climate Change, which was held on March 30-31, 2009. Id. $\$ 114$. The information discussed at the summit was used to create a framework for the climate change committee's study. The Committee on America's Climate Choices (referred to as the Climate Change Study Committee in the 
temperature has risen substantially over the past century, especially over the last three decades; ${ }^{37}$ that most of the recent warming is attributable to fossil fuel combustion and other human activities that release $\mathrm{CO}_{2}$ and other heat-trapping gases; ${ }^{38}$ and that the magnitude of climate change and the severity of its impacts will depend on the actions that human societies take to respond to these risks. ${ }^{39}$

Despite these findings, a debate continues over the existence, causes, and importance of climate change. This may be due to the distrust that exists between the public and the scientific community. ${ }^{40}$ The gap between scientific and public opinion should be narrowed by the growing number of publicly respected institutions and leaders that have embraced scientific opinion. The Securities and Exchange Commission, for example, now requires companies to disclose material consequences of future climate change on their business. ${ }^{41}$ The Department of Defense has identified that climate change "may act as an accelerant of instability or conflict," as well as "contribute to food and water scarcity . . . [and] increase the spread of disease." 42 A study cochaired by a retired Navy admiral found that given the IPCC projections, the "projected changes would affect U.S. national security and stress naval resources." 43 The Vatican sent a representative to the United Nations Conference on Climate Change to promote the adoption of "effective mitigation and adaptation [strategies] to ongoing climate change." ${ }^{44}$ Following

Act) was composed of a diverse group of experts from academia, the government, and the private sector. After the Committee generated a report, independent evaluators reviewed the report pursuant to the NRC's Report Review Committee procedures. Subsequent to the review and changes pursuant to the review, the final report on America's Climate Choices was released to the public, targeting primarily decision makers at all levels of government in America.

37. AMERICA'S Climate CHOICES, supra note 35, at 15.

38. Id. at 16 .

39. Id. at 24-25.

40. Caren B. Cooper, Media Literarcy as a Key Sirategy Toward Improving Public Acceptance of Climate Change Science, 61 BloScIENCE 231, 231 (2011).

41. Commission Guidance Regarding Disclosure Related to Climate Change, Financial Reporting Release, 75 Fed. Reg. 6290, 6295-97 (Feb. 2, 2010) ("[This guidance] will not be published in the Federal Register/Code of Federal Regulations," but is instead found in the "Codification of Financial Reporting Policies.").

42. DEP'T OF DEF., QUADRENNIAL DEFENSE REVIEW REPORT 85 (2010).

43. NAT'L RESEARCH COUNCIL, NATIONAL SECURITY IMPLiCATIONS OF Climate ChANGE FOR U.S. NAVAL FORCES 6 (2010).

44. Celestino Migliore, Statement of H.E. Msgr. Celeslino Migliore Permanent Oberserver of 
this meeting at Copenhagen, the Pope "denounced the failure of world leaders to agree to a new climate change treaty." 45 The global insurance community has identified climate change as a threat to many areas. ${ }^{46}$ Swiss Reinsurance, for example, has estimated that the "U.S. Gulf Coast could face average annual losses of up to USD 23 billion and cumulative economic damages of USD 350 billion from climate risks" if no adaptation measures are implemented ${ }^{47}$ Some insurance companies now offer products that "require a payout when a particular index (heat degree days, amount of rain or snowfall, etc.) is triggered." 48 Other insurance products offer incentives to consumers who reduce climate change risks by lowering their emissions and utilizing green technology. ${ }^{49}$

The Supreme Court recognized the seriousness of climate change in Massachusetts $v . E P A .{ }^{50}$ In the majority opinion, Justice Stevens wrote:

The harms associated with climate change are serious and well recognized. Indeed, the NRC Report itself-which EPA regards as an "objective and independent assessment of the relevant science," identifies a number of environmental changes that have already inflicted significant harms, including "the global retreat of mountain glaciers, reduction in snow-cover extent, the earlier spring melting of ice on rivers and lakes, [and] the accelerated rate of rise of sea levels during the 20th century relative to the past few thousand years ...." 51

the Holy See to the United Nations Organization, THE SECRETARIAT OF STATE, http://www.vatican.va/roman_curia/secretariat_state/2009/documents/rc_segst_200912 17_migliore-copenaghen_en.html (last visited Mar. 7, 2012).

45. Sabina Castelfranco, Pope Denounces Failure of Copenhagen Climate Change Negotiations, VOICE OF AM. (Jan. 12, 2010), available al http://www.voanews.com/english/ news/Pope-Denounces-Failure-of-Copenhagen-Climate-Change-Negotiations-81225017 .html.

46. Leslie Kaufman, A City Prepares for a Warm Long-Term Forecast, N.Y. TiMES, May 22, 2011 , at A1.

47. US Gulf Coast Could Face Average Annual Losses of Up to USD 23 Billion by 2030, SwISS REINSURANCE (Oct. 20, 2010), http://www.swissre.com/media/news_releases/ US_Gulf_Coast_could_face_average_annual_losses_of_up_to_USD_23_billion_by_2030_a nd_cumulative_economic_damages_of_USD_350_billion_from_climate_risks_says_Swiss_R e_research.html.

48. Gary S. Guzy, Insurance and Climate Change, in Global Climate Change AND U.S. L.AW 541, 556 (Michael Gerrard ed., 2007).

49. Id at $557-58$.

50. 549 U.S. 497 (2007).

51. Id. at 521 (citation omitted). 


\section{The Sequestration Strategy: Targeting the Lands THat MATTER}

Carbon sequestration reduces atmospheric $\mathrm{CO}_{2}$ levels by storing carbon for the long term. Sequestration includes both biological and physical measures. Biological sequestration occurs when places like forests, pastures, meadows, and other vegetated landscapes naturally absorb and store carbon. Physical sequestration, on the other hand, involves mechanically capturing and storing carbon produced when coal or other carbon-intensive fuels are burned.

Physical sequestration involves vast engineering projects that capture, compress, and transport $\mathrm{CO}_{2}$ to a storage site, create underground geologic storage capacity, or use the ocean for $\mathrm{CO}_{2}$ storage. ${ }^{52}$ Physical, or engineered, sequestration of this type is referred to in climate change law as Carbon Capture and Sequestration (CCS). The law and the technology of CCS are in their infancy. ${ }^{53}$ Scientific uncertainties, potential adverse environmental impacts, legal barriers, technological and accounting difficulties, and the expense associated with these techniques have limited the utility of CCS for the present. ${ }^{54}$

There is no unified regulatory system for CCS projects. Instead, there are various uncoordinated local, state, and federal regulations that apply. ${ }^{55}$ The applicability of the Clean Air Act to the mechanical systems and technologies involved is uncertain, and state law is in its formative stages regarding the regulation of

52. Matt Richtel, Recruiting Plankton to Fight Global Warming, N.Y. TIMES, May 1, 2007, http://www.nytimes.com/2007/05/01/business/01 plankton.html?pagewanted=1\&sq=car bonsequestrationocean\&st=Search\&scp=2; Matthew L. Wald, Tucking Carbon into the Ground, N.Y. Times, Mar. 30, 2011, at F3.

53. Victor B. Flatt, Paving the Legal Path for Carbon Sequestration from Coal, 19 DUKE ENVTL. L. \& POL'Y F. 211, 213-14 (2009).

54. INTERAGENCY TASK FORCE ON CARBON CAPTURE AND STORAGE, EXECUTIVE SUMMARY: REPORT OF THE INTERAGENCY TASK FORCE ON CARBON CAPTURE AND STORAGE (2010), available al http://www.epa.gov/climate change/downloads/ES-CCS-Task-ForceReport-2010.pdf ("Administration analyses of proposed climate change legislation suggest that CCS technologies will not be widely deployed in the next two decades absent financial incentives that supplement projected carbon prices. In addition to the challenges associated with cost, these projects will need to meet regulatory requirements that are currently under development. Longstanding regulatory programs are being adapted to meet the circumstances of CCS, but limited experience and institutional capacity at the Federal and State level may hinder implementation of CCS-specific requirements. Key legal issues, such as long-term liability and property rights, also need resolution.").

55. See Flatt, supra note 53, at 214-15. 
CCS systems. ${ }^{56}$ When underground storage of captured carbon is involved, complicated property rights issues inevitably arise, including surface rights to the land where the pumps and equipment are located, rights to underground caverns where the carbon is stored, and potential property rights in the stored carbon itself. ${ }^{57}$ Ownership interests in groundwater that is in proximity to the carbon storage areas are also implicated. ${ }^{58}$ In order for a CCS system to work, all these property rights may need to be purchased, leased, or licensed, and held by the operating entity and all of the respective liabilities negotiated, adding transactional complexity.

Biological sequestration, on the other hand, is less complex. It happens organically, and scientists can measure the sequestration capacities of various resources. This type of sequestration can be advanced cost-effectively under current technology, using mature legal strategies. ${ }^{59}$ Land-use regulations, for example, can preserve and expand landscape features that have significant potential to sequester carbon. The IPCC's climate change reports indicate that cost-effective land-use strategies that involve biological sequestration are capable of achieving between 345 and 1260 gigatons of $\mathrm{CO}_{2}$ equivalent stabilization by 2100 at the global level. 60 The magnitude of this figure can be appreciated by understanding that current, annual global carbon dioxide emissions were approximately thirty-eight gigatons in $2004 .{ }^{61}$ The IPCC identifies such land use strategies as important climate change mitigation techniques. ${ }^{62}$ In the United States, eighteen percent of carbon emissions are captured annually through biological sequestration. ${ }^{63}$ Virtually no carbon capture is attributed currently to CCS.

Population growth and increased urbanization affect biological sequestration in a variety of ways. As the population grows, more

56. Id. at 212-14; Christa Marshall \& Evan Lehmann, AEP Move to Stop Carbon Capture and Sequestration Project Shocks Utilities, Miners, N.Y. TimES, July 15, 2011, available at http://www.nytimes.com/cwire/2011/07/15/15climatewire-aep-move-to-stop-carboncapture-and-sequestr-83721.html?pagewanted=all.

57. See Flatt, supra note 53, at 229-30.

58. Id. at 234-35.

59. David J. Hayes \& Joel C. Beauvais, Carbon Sequestration, in Global Climate Change AND U.S. LAW 691, 691-92 (Michael B. Gerrard ed., 2008).

60. IPCC SYNTHESIS REPORT, supra note 28 , at 41 .

61. Id. at 36 .

62. Id. at 61 .

63. EPA GREENHOUSE GAS INVENTORY, supra note 4, at ES-13. 
residential and nonresidential development occurs. ${ }^{64}$ If new development follows the current pattern of urban sprawl, large amounts of vegetated lands that currently sequester carbon will be converted to development. Doubling the average density of dwelling units to accommodate the projected increase of 100 million people, for example, would preserve an undeveloped area roughly the size of Connecticut and greatly reduce the loss of sequestering resources. ${ }^{65}$ Curtailing sprawl through urban revitalization efforts is a key component of climate change management and should be part of the nation's biological sequestration policy. ${ }^{66}$

Croplands, grasslands, meadows, and forests yield to the pressures of suburbanization at the outer edge of urban growth patterns. As the population grows, more food will be needed, putting pressure to convert sequestering resources such as forests, meadows, and grasslands in rural areas to farmland. It is in these places that land-use law can be particularly effective in designating and protecting lands that sequester carbon as a key mitigation

64. By 2039 , the population of the United States will have grown to over 400 million people, a dramatic increase of 100 million people since 2006. U.S. Population Hits 300 Million Mark, MSNBC, http://today.msnbc.msn.com/id/15298443 (last visited Sept. 17, 2006); U.S. Population Projections, U.S. CENSUS BUREAU, http://www.census.gov/population /www/projections/summarytables.html (follow "Projections of the Population and Components of Change for the United States: 2010 to 2050") (last visited July 25, 2011). By 2050 , it is projected that America will add 89 million new and replacement residential units and 190 billion square feet of nonresidential construction to accommodate this growth and to replace obsolete buildings. TRANSP. RESEARCH BD., NAT'L RESEARCH

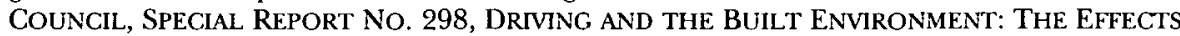
of Compact Development on Motorized Travel, Energy USE, AND CO2 EMISSIONS 121 (2009); Memorandum from Reid Ewing, Arthur C. Nelson, \& Keith Bartholomew, Response to Transp. Research Bd. Special Report 298 Driving and the Built Environment: The Effects of Compact Development on Motorized Travel, Energy Use, and $\mathrm{CO}_{2}$ Emissions (Sept. 16, 2009), available al http://www.smartgrowthamerica.org/documents/ Response toTRBSpecial Report.pdf.

65. The Land Use Stabilization Wedge Strategy, supra note 1, at 14 ("At a density of 15, rather than 7.5 dwelling units per acre, 40 million new households will consume half as much land. At 7.5 units per acre, these households will occupy nearly 5.5 million acres for housing alone. Doubling the net density per acre reduces that figure to roughly 2.5 million acres, a savings of nearly three million acres, just under 5,000 square miles: an area about the size of the state of Connecticut."). The area of Connecticut is 4845.4 square miles. Connecticut Population, Land Area, and Density by Location, CONN. DEP'T OF ECON. \& CMTY. DEv., http://www.ct.gov/ecd/cwp/view.asp?A=1 106\&Q=250664 (last visited Feb. 8, 2012).

66. Using the land use system to address growth patterns by attracting new populations to revitalized urban settlements in the interest of climate change mitigation is addressed in The Land Use Slabilization Wedge Strategy, supra note 1. See infra Parts IV \& V. 
strategy. At the same time, open space policies in developing and developed places, while adding marginally to sequestration, are effective strategies to adapt to climate change. With federal and state assistance, local governments can shape land development to reduce land coverage and impervious surfaces, limit flooding, retain and add vegetation, protect community character, and prevent ground and surface water pollution. In highly developed cities, tree canopies can be increased; green infrastructure added; urban gardens promoted; and buildings oriented to reduce the heat island effect, ${ }^{67}$ make cities attractive and lively places to live, and mute the effects of higher densities needed near transit stations. ${ }^{68}$ As suburban subdivisions are developed, they can be better situated into the existing vegetated landscape through thoughtful land use regulations. These are adaptation techniques; as climate change progresses, it will be necessary to adapt to its effects by preserving and expanding the vegetated environment so as to cope with increased temperatures and other climatic changes.

All of these lands matter when open space policies are crafted. Sequestration's emphasis on retaining and expanding the vegetated environment has multiple applications, from mitigating climate change by capturing and storing carbon, to softening the impact of new development, to adapting urban environments to a changing climate. A national biological sequestration policy has applicable to urban, suburban, and rural areas and embraces a variety of methods of preserving and enhancing the vegetated environments in each.

\section{OPEn SPACE LAW: STATE AND LOCAL ORIGINS}

\section{A. Using Open Space Law to Accomplish Sequestration}

Robert Socolow's Stabilization Wedge Strategy posits that there are ample avenues to mitigate climate change using existing

67. In urban places, extensively paved areas, rooftops, and other hard-scape development creates high-temperature heat islands in cities and areas immediately downwind from them. To mitigate this effect, urban tree canopies must be expanded and other vegetation added to the streets, sidewalks, parks, and roof tops. U.S. EPA, REDUCING URBAN HEAT ISLANDS: COMPENDIUM OF STRATEGIES: URBAN HEAT ISLAND BASICS 1 (2008), available at http://www.epa.gov/hiri/resources/pdf/BasicsCompendium.pdf.

68. U.S. GREEN BLDG. COUNCIL, LEED 2009 FOR NEIGHBORHOOD DEVELOPMENT $73-$ 74 (2011) (categorized as "NPD Credit 13: Local Food Production"). 
technologies. ${ }^{69}$ This is significant, since norms have a great deal to do with change. ${ }^{70}$ National policies are proposed that are not normative, resistance is stiffer and change takes longer; where they conform with existing norms, as is the case with efforts to preserve open space, strategies have a better chance of being accepted and effective. ${ }^{71}$ We turn here to Open Space Law; its maturation over the past several decades demonstrates that preserving the lands that sequester carbon through land-use law is normative and, thus, has a realistic chance of achieving political consensus and becoming a national approach to climate-change management.

Open Space Law is seldom taught, as such, in American law schools and it is only infrequently referred to by that term in the literature. A large number of existing laws, however, do result in the preservation and protection of sequestering open space. Some function at the level of the individual site, some at the subdivision or neighborhood level, and still others at a community-wide or even regional level. ${ }^{72}$ These existing laws pursue an impressive array of objectives including nongrowth, ${ }^{73}$ provision of recreation

69. Pacala \& Socolow, supra note 2, at 970.

70. EVERETT M. Rodgers, Diffusion OF InNOVAtions 26 (5th ed. 2003) ("Norms are the established behavior patterns for the members of a social system. Norms define a range of tolerable behavior and serve as a guide or standard for the behavior of members of a social system. The norms of a system tell individuals what behavior is expected. . . . Norms can operate at the level of a nation, a religious community, an organization, or a local system such as a village.").

71. Open space preservation is normative in most communities, while accepting affordable housing, wind turbines, or solar arrays might not be. At the national level, resistance to a carbon tax and cap and trade system can be understood, in part, because of their novelty. Alternative fuels and cars are becoming normative as gas prices increase and the recession continues. INT'L ENERGY AGENCY, TECHNOLOGY ROADMAP: ELECTRIC AND Plug-IN HYBRID ELECTRIC VEHICLES 8 (2011) (noting that despite only being available for the past decade, "as of early 2011 [electric vehicle] market penetration is approaching $2 \%$ in the United States" with "over 2.5 million $\mathrm{HEV} / \mathrm{PHEV} / \mathrm{EV}$ vehicles" sold worldwide).

72. Recently, low-impact development and sustainable site regulations have evolved; cluster zoning or subdivisions have been used for three decades to reduce lot size for single-family subdivisions in the interest of preserving open space at the subdivision or neighborhood level; and many regional watershed efforts have been formed by environmental groups or intermunicipal compacts of adjacent communities for the purpose of coordinating land use regulations throughout a shared watershed. See discussion infra Parts IV \& V for more information.

73. Earl Finkler \& David L. Peterson, Nongrowth Planning Strategies: The DEVELOPING POWER OF TOWNS, CITIES, AND REgIONS viii (1974) ("Nongrowth is a new and exciting concept. . . . It is possible that the idea of nongrowth will develop into a new field in itself, expanding, altering, and perhaps replacing 'planning' as it is now conceived, and bringing about substantial shifts in the character of the legal and economic professions. This new field of growth analysis may prompt the development of more Renaissance men 
services, ${ }^{74}$ enhanced wildness and community character, ${ }^{75}$ and the preservation of any number of community and regional assets such as green space, $^{76}$ agricultural land, ${ }^{77}$ watersheds, ${ }^{78}$ habitats, ${ }^{79}$

and women who can gain some overview of the many fields it touches.").

74. ERIC Damian KELIY \& Barbara BEcker, COMMUNITY PlanNing: AN INTRODUCTION TO THE COMPREHENSIVE PLAN 301 (2000) ("Preservation of open space today is a major priority of many local governments. .. . The emphasis of such planning was once on formal parks and areas suitable for such active recreation uses as softball, soccer, tennis, and picnicking. . . . Parks remain important. The National Recreation and Park Association ... guidelines . . recognize the importance of other types of open space and greenways. A 1996 plan for Ames, Iowa, calls for five acres of park land for every thousand residents and an additional five acres of 'woodlands/open space' for every thousand residents."). Developers of subdivisions can be required to set aside land to provide recreation for the new residents of the communities. See N.Y. GEN. CITY LAW $\$ 37$ (McKinney 2011); N.Y. TOWN LAW \$ 278 (McKinney 2011); N.Y. VILLAGE LAW § 7-738 (McKinney 2011).

75. John Turner \& Jason Rylander, Land Use: The Forgotten Agenda, in THinking ECologically: The Next Generation of Environmental Policy 60, 74 (Marian R. Chertow \& Daniel C. Esty eds., 1997) ("Improved land use policies will need to be based on a systems approach that reduces the waste of land and resources, enhances wildness and community character, permits growth and economic development, and preserves healthy and functioning ecosystems. 'No net loss of greenspace' should be a goal for the twenty-first century. We must find ways to accommodate projected future growth while preserving open space, farmland, watersheds, and rural communities.") [hereinafter THINKING ECOLOGICALLY]

76. Paul Cawood Hellmund \& Daniel Somers Smith, Designing Greenways: Sustainable LANDSCAPES FOR NATURE AND PEOPLE 227 (2006) ("Increasingly residents and officials of metropolitan and other areas across North America are taking steps to ensure that there will be greenspace left at the 'end of the day.' In many urbanizing locales this amounts to a kind of 'creative fragmentation,' working to identify and save key components of greenspace in advance of development, accepting that development will come and natural areas will become fragmented and potentially isolated. The challenge is in knowing which pieces to save and how these eventual remnants will function once their matrix has dramatically changed.").

77. JAMES M. MCELfiSh, JR., ENVTL. LaW InST., NATURE-Friendly Ordinances: LOCAL MEASURES TO CONSERVE BIODIVERSITY 47 (2004) (“Agricultural protection zoning designates an area as an agricultural district subject to specific regulation under the zoning laws. Typically, in such zones agricultural uses are permitted as of right, while nonfarm uses are either prohibited or allowed subject to certain conditions. This use restriction may be combined with other restrictions such as prohibitions on the subdivision of agricultural land or requirements that subdivisions result in parcels that are quite large. Related techniques include large minimum lot sizes, cluster development or conservation development requirements, limits on the number of building permits authorized for the zone, and regulations confining buildable areas within the zone to poorer soils or smaller tracts.").

78. CTR. FOR WATERShed PRot., Rapid Watershed PlanNing HaNdboOK: A COMPREHENSIVE GUIDE FOR MANAGING URBANIZING WATERSHEDS 2.3 (1998) ("Watershed planning is best conducted at the subwatershed scale, where it is recognized that stream quality is related to land use and consequently impervious cover. One of the goals of watershed planning is to shift development toward subwatersheds that can support a particular type of land use and/or density. The basic goal of the watershed plan is to apply 
biodiversity, ${ }^{80}$ sensitive environmental resources, ${ }^{81}$ riparian lands, ${ }^{82}$ surface water bodies, ${ }^{83}$ wetlands, ${ }^{84}$ and ecosystem services, ${ }^{85}$ to

land use planning techniques to redirect development, preserve sensitive areas, and maintain or reduce the impervious cover within a given subwatershed.").

79. James McDougal, Conservation of Tontoises and Terrestrial Turtles, in TURTLE CONSERVATION 180, 193-94 (Michael W. Klemens ed., 2000) ("Habitat destruction is one of the primary factors responsible for the extinction and extirpation of many species today. Although effects of the outright destruction of habitat are obvious and well known, other forms of habitat destruction that are more subtle and harder to observe may also negatively affect populations of organisms. For example, the phenomenon of habitat fragmentation is of major concern for biological conservation today and indeed has been called the primary cause of the present extinction crisis. Fragmentation may be understood as the progressive reduction of a species' requircd habitat to the point at which the habitat area exists as a number of remnant patches surround by and separated from each other by a matrix of suboptimal or nonusable space. . . Habitats can be fragmented by the building and expansion of human settlements; either rural or urbansuburban, and the associated infrastructure (such as roads); by intensive agricultural development and expansion; by deforestation; or by any other processes that subdivide an organism,s habitat into smaller and smaller areas.") (citations omitted).

80. Oliver A. Houck, Foreword to BIOdIVERSITY AND THE LAW xiii. (William J. Snape III ed., 1996) ("Two-thirds of America is privately owned, however, and the states with the greatest numbers of vanishing species and ecosystems are those that have been subject to the most rapid private development: Florida, California, and Hawaii. Mechanisms to preserve biological diversity on private lands include conservation easements, tax reductions, and endangered lands purchase programs, but in their aggregate they remain dwarfed by the pace of private land development itself.").

81. Randall arendt, Growing Greener: Putting Conservation into local PLANS AND ORDINANCES 63 (1999) ("As a rule of thumb, the first four features listed above-wetlands, floodplains, slopes and soils-take first priority for inclusion in the designated open space, as they represent highly sensitive environmental resources that are generally considered to be unbuildable in a legal sense, in a practical sense, or for reasons of common sense. They should be placed in Primary Conservation Areas, the first type of open space to be drawn on any site plan.").

82. Comm. ON Riparian ZONE FUnCTIONING AND STRATEgies fOR MgMT., NAT'L RESEARCH COUNCIL, RIPARIAN AREAS: FUNCTIONS AND STRATEGIES FOR MANAGEMENT 227 (2002) ("Most riparian lands are in private ownership, especially in the eastern portion of the United States. The value of riparian lands to a private landowner most often is measured in terms of their economic benefits rather than their ecological functions. Private owners of riparian lands typically have only limited motivation to us these areas in a manner protective of their functions. In the absence of improved education about riparian functioning, legal strategies for protecting the ecological values of privately owned riparian lands must be based either on implementing regulatory requirements or on providing special incentives. Alternatively, such areas may be purchased for public ownership and management.").

83. William B. Honachefsky, Ecologically Based MUNicipal Land Use PLANNING 57 (2000) ("[T] he water resources of the community, particularly the surface waterways and their concomitant watersheds (drainage areas), have major importance in the ecologically based MMP [municipal master plan]. Other than air, no other resource impinges so directly on the day-to-day well-being of every living creature of the biosphere including man.").

84. Dennis W. Magee, A Primer on Welland Ecology, in WeTlands LaW and Policy: 
name but a few. As the footnotes to this paragraph illustrate, there is no dearth of scholarship on Open Space Law when the field is broken down into its substantive components. With very few exceptions, however, these works and the laws they describe have not focused on sequestration as a public objective. ${ }^{86}$

\section{B. Legality of Local Sequestration Laws}

The legal authority to adopt land use regulations is delegated to local governments by the legislatures of the fifty states under their police power to adopt laws to protect the public health, safety, and welfare. The police power is broadly defined and courts defer to legislative acts that further police power objectives. ${ }^{87}$ Local

Understanding SECTION 404, at 27, 28 (Kim Diana Connolly et al. eds., 2005) ("[T] he U.S. Fish and Wildlife Service (FWS) defines wetlands as transitional lands that occur between upland and aquatic environments, where the water table is usually at or near the surface, or the land is covered by shallow water. For purposes of the Clean Water Act's Section 404 program, the United States Army Corps of Engineers (Corps) and the U.S. Environmental Protection Agency (EPA) define wetlands as areas inundated or saturated by surface or groundwater at a frequency and duration sufficient to support, and that under normal circumstances do support, a prevalence of vegetation typically adapted for living under saturated soil conditions. . . In addition to the definitions developed by federal agencies, many states and local communities have developed separate definitions based on hydrology, soils, vegetation, and various combinations thereof. In recent years, there has been a tendency for many states to bring their definitions into consistency with the federal definition to simplify the regulatory process.").

85. HONACHEFSKY, supra note 83 , at 57.

86. Craig R. Groves, The nature Conservancy, Drafting a Conservation BluEPrint: A PRACTITIONER'S GUIDE TO PLANNING FOR BIODIVERSITY 346-47 (2003) ("Given that climate shifts will accelerate and not all species will thrive where they currently do, some redistribution of plants and animals is a certainty. However, the patterns of this redistribution will be species-specific and highly unpredictable, so the ecoregion planner's job is not to prepare for some ill-defined, distant, theoretical equilibrium conditions, but to identify potential short-term refugia. These will comprise some existing conservation areas and their suitable adjacent 'up-slope' habitats (cooler, higher above sea level, etc.). Conservation planning can identify refugia where species and ecosystems are most likely to persist for decades to centuries in an unstable and unpredictable environment. Properly implemented, conservation planning might also be a tool for minimizing the emission of greenhouse gases from natural landscapes, thus potentially slowing the pace of climate change to a rate nearer the natural adaptive capacity of species and ecosystems.").

87. MCELFISH, supra note 77, at 4 ("Development regulations and land use plans must take the natural environment into account. They can deal with conservation of biodiversity. State enabling acts typically define the land use powers of local governments, and/or confer home-rule powers. In virtually all states there are explicit provisions in state law that recognize local government powers to conserve open space, natural resources, water quality, and provide in similar ways for the general welfare. Some states have explicit requirements that such values be included in comprehensive plans and zoning ordinances, while others make such provisions permissive. Whatever the source, local governments 
zoning and land use laws are adopted by local town, city, and village councils and boards, which are legislative bodies that enjoy the full deference of judges when their actions are challenged as going beyond the scope of their delegated authority. In Moviematic Industries Corp. v. Dade County, ${ }^{88}$ for example, Florida property owners challenged a rezoning of an area from heavy industry to large lot single family housing over 300 acres of the Biscayne Aquifer, a major source of the county's drinking water. The court found that the county's home-rule charter gave it powers to enact zoning laws to assure an adequate water supply for the protection of the public. Specifically, the court held "that preservation of the ecological balance of a particular area is a valid exercise of the police power as it relates to the general welfare." 89

A number of state courts have held that the preservation of agricultural or timberland is a legitimate land-use objective under the delegated police powers. ${ }^{90}$ Protection of wetlands or floodplains, soil conservation and related ecological goals have also passed muster in the courts as proper regulatory goals. ${ }^{91}$ Other ends, such as the protection of wildlife habitat and scenic vistas, are increasingly being accepted as legitimate state objectives in land-use regulation and these are features often associated with forests, undeveloped space, and agricultural lands. ${ }^{92}$

Local governments, in most states, may exercise only those powers delegated to them by their state legislatures. From state to state, the methods of delegating authority to protect the environment vary. In some states, the legislatures deem the historical zoning enabling act sufficient to justify local regulations that protect open space. The Standard Zoning Enabling Act promulgated by the United States Department of Commerce in

exercise powers that can have a profound effect on the biological health of their lands and waters.") (footnote omitted).

88. 349 So.2d 667 (Fla. Dist. Ct. App. 1977).

89. Id. at 669 .

90. See Gisler v. Cnty. of Madera, 112 Cal. Rptr. 919, 920 (Cal. Ct. App. 1974); Gardner v. N.J. Pinelands Comm'n, 593 A.2d 251, 263-64 (N.J. 1991); Codorus Twp. v. Rodgers, 492 A.2d 73, 84-85 (Pa. Commw. Ct. 1985).

91. See, e.g., Woodbury Cnty. Soil Conservation Dist. v. Ortner, 279 N.W.2d 276, 279 (lowa 1979) (holding that soil conservation is a legitimate purpose for the exercise of police power).

92. See, e.g., Furey v. City of Sacramento, 780 F.2d 1448, 1454 (9th Cir. 1986) (holding that the designation of agricultural land as open space was not a taking even though it deprived the owners of sewer improvements), abrogated on other grounds by Schnuck v. City of Santa Monica, 935 F.2d 171, 173 (9th Cir. 1991). 
the 1920s contains a provision that zoning authority may be exercised to encourage "the most appropriate use of the land." ${ }^{3}$ This language remains today in many state enabling acts and is used by some state courts with broad views of implied local power to affirm the authority of municipalities to protect the environment. ${ }^{94}$

Under the New York Municipal Home Rule Law, localities are given the authority to adopt laws relating to their "property, affairs or government" 95; to "the protection and enhancement of [their] physical and visual environment" ${ }^{96}$; and to the matters delegated to them under the statute of local governments. ${ }^{97}$ The statute of local governments delegates to municipalities the power "to adopt, amend and repeal zoning regulations" 98 and to "perform comprehensive or other planning work relating to its jurisdiction." ${ }^{99}$ These, in the aggregate, provide powerful authority for local governments to regulate private property to protect their physical environments in the broad interest of the public.

In North Carolina, the state legislature adopted a legislative rule broadly construing the powers delegated to local governments. ${ }^{100}$ Prior to that time, the courts applied Dillon's rule, strictly construing specific grants of authority to local governments. The City of Raleigh's requirement that a developer must create open space in a subdivision and convey title to it to a private homeowners' association was upheld using this legislative rule of construction. ${ }^{101}$ The reach of this rule is evident in Homebuilders Association of Charlotte $v$. City of Charlotte, where the power to impose

93. DEP'T OF COMMERCE, A STANDARd STATE ZONING ENABling ACT UNDER WHich MUNiCIPALITIES MAY ADOPT ZONING REgUlATIONS $§ 3$ (1926) [hereinafter STANDARD STATE ZONING ENABLING ACT].

94. N.Y. TOWN LAW $§ 263$ (McKinney 2011); CONN. GEN. STAT. ANN. § 8-2(a) (West $2011)$.

95. N.Y. MUN. HOME RULE LAW § 10(1)(i) (McKinney 2011).

96. Id. $\$ 10(1)$ (ii) (a) (11).

97. Id. $\S 10(1)$.

98. N.Y. STAT. LOCAL GOV'TS $§ 10(6)$ (McKinney 2011).

99. Id. §10(7).

100. N.C. GEN. STAT. ANN. $§ 160 A-4$ (West 2011) ("It is the policy of the General Assembly that the cities of this State should have adequate authority to execute the powers, duties, privileges, and immunities conferred upon them by law. To this end, the provisions of this Chapter and of city charters shall be broadly construed and grants of power shall be construed to include any additional and supplementary powers that are reasonably necessary or expedient to carry them into execution and effect.").

101. River Birch Assocs. v. City of Raleigh, 388 S.E.2d 538, 542 (N.C. 1990). 
user fees on applicants for rezoning, special use permits, plat approvals, and building inspections was upheld in the absence of expressly delegated authority. ${ }^{102}$ How far the North Carolina courts will go in upholding local environmental laws under this rule is not known. Some have argued, however, that a state's zoning enabling statute which allows localities to regulate the percentage of lots that may be occupied, as well as the size of yards, courts, and other open spaces, "provides authority to require buffers along waterways, to protect important natural areas, and to set requirements that authorize or even mandate clustered development schemes." 103

Connecticut statutes give local zoning commissions flexibility to design individual programs to meet municipal development and conservation needs and to take into account unique local environmental conditions. ${ }^{104}$ The Connecticut state legislature has provided towns and cities authority to protect the environment, ${ }^{105}$ to acquire open space lands from private owners, ${ }^{106}$ and to establish conservation commissions. ${ }^{107}$ Localities can also purchase development rights on agricultural land. ${ }^{108}$ State statutes establish a detailed system for the creation of an inland wetlands and watercourse protection regime that allows local wetland agencies to have significant control over development affecting wetlands and watercourses. ${ }^{109}$ Local governments in Connecticut can adopt wetlands regulations that are stricter than the wetlands standards of the state. ${ }^{110}$ Applications made to local review agencies seeking development approval must contain a soil erosion and sediment control plan. ${ }^{111}$ In addition, local zoning and subdivision regulations must make proper provision for soil erosion and

102. 442 S.E. $2 d$ 45, 50-51 (N.C. 1994).

103. David W. Owens, Local Government Authority to Implement Smart Growth Programs: Dillon's Rule, Legislative Reform, and the Current State of Affairs in North Carolina, 35 WAKE FOREST L. REV. 671, 701 (2000).

104. See Michael A. Zizka, Conn. Dep't of Energy \& Envtl. Prot., What's LEGAlLY REQUiRED? A GUIDE TO THE LEGAL RULES FOR MAKING LOCAL LAND-USE DECISIONS IN THE STATE OF CONNECTICUT 55 (1997).

105. CONN. GeN. Stat. ANN. \$7-148(c) (8) (West 2011).

106. Id. $\$ 7-131 \mathrm{~b}(\mathrm{a})$.

107. Id. $\$ 7-131 \mathrm{a}(\mathrm{a})$.

108. Id. $\$ 7-131 \mathrm{q}(\mathrm{e})$.

109. Id. $\$ \S 22 \mathrm{a}-36$ to -45 .

110. Aaron v. Conservation Comm'n of Redding, 441 A.2d 30, 37 (Conn. 1981).

111. CONN. GEN. STAT. ANN. \$22a-329 (West 2011). 
sediment control. ${ }^{112}$

The following partial listing of additional state statutes indicates that this trend toward state activism regarding open space protection and enhancement is robust:

- The State of Maine requires every county to adopt a forest stewardship ordinance. ${ }^{113}$ Individual county forest laws then govern the timber industry by imposing best management practices on private forest owners prior to harvesting timber.

- The Forest Conservation Act of Maryland requires that all municipalities in the state have a forest conservation ordinance. ${ }^{114}$ The state Natural Resources Department maintains a list of best practices for forest conservation that must be followed by developers who are building under a local forest conservation ordinance. ${ }^{115}$

- Washington State requires that local governments not only designate critical areas and adopt development regulations to protect these areas in their comprehensive plans, but also to use the best available science when these regulations are adopted. ${ }^{116}$ The Washington statute also requires that each county and city in Washington identify significant agricultural, forest, and mineral resource lands and other defined critical areas. ${ }^{117}$

- Under California's Environmental Quality Act, local agencies must prepare an environmental impact report on any project that they intend to carry out or approve that may have a significant effect on the environment. ${ }^{118}$ California's Open Space Lands Act requires every city and county to adopt a local open space plan for the long-term preservation of open space lands within its jurisdiction. ${ }^{119}$ The plan must be submitted to the Secretary of the

112. Id.

113. ME. Rev. STAT. ANN. tit. 12, $\$ 8869(8)$ (West 2011).

114. MD. CODE ANN., NAT. RES. § 5-1603 (West 2011).

115. MD. DEP'T OF NATURAL RES., STATE Forest CONSERVATION TECHNiCAL MANUAL (Ginger Page Howell \& Tod Ericson eds., 3d ed. 1997), available at http://www.dnr.state .md.us/irc/docs/00010950.pdf.

116. WASH. REv. CODE ANN. § 36.70A.172 (West 2011).

117. Id. $\$ 36.70 \mathrm{~A} .170$.

118. CAL. PUB. RES. CODE $\S \S 21000-21177$ (West 2011).

119. CAL. GOV’T CODE $\$ \S 65302(\mathrm{e}), 65563-70,65910$ (West 2011). 
Resources Agency.

- Massachusetts requires local governments to report on mitigation measures and alternatives to proposed actions, as well as on anticipated environmental impacts. ${ }^{120}$

- Vermont's Act 250 gives state entities land-use approval power regarding certain large-scale or high-impact land development projects. ${ }^{121}$ Statutorily defined developments in Vermont require a permit from the state, independent from and in addition to any local regulation or permits. To qualify for such a permit, the development must meet ten criteria. ${ }^{122}$ These include findings that the development will not have an undue adverse effect on the scenic or natural beauty of the area and will not destroy or significantly imperil necessary wildlife habitat.

- Local governments in Florida are required to incorporate conservation elements into their comprehensive plans. These elements must be designed for the conservation, use, and protection of natural resources in the community, including wetlands, estuarine marshes, soils, beaches, shores, flood plains, rivers, bays, lakes, forests, fisheries and wildlife, and marine habitat. ${ }^{123}$

\section{State Financing of Open Space Acquisition}

States support open space preservation in a number of ways that involve taxes, state bonds, tax exemptions, local financing

120. MASS. GEN. LAWS ANN. ch. 30, \$§61-62I (West 2011 ).

121. VT. STAT. ANN. tit. 10, $\$ \$ 6001-93$ (West 2011).

122. Id. $\$ 6086(\mathrm{a})(1)-(10)$ (requiring that development "will not result in undue water or air pollution"; "[d]oes have sufficient water available for the reasonably foreseeable needs of the ... development"; "[w] ill not cause an unreasonable burden on an existing water supply, if one is to be utilized"; "[w]ill not cause unreasonable soil erosion or reduction in the capacity of the land to hold water so that a dangerous or unhealthy condition may result"; "[w]ill not cause unreasonable congestion or unsafe conditions with respect to use of the highways, waterways, railways, airports and airways, and other means of transportation existing or proposed"; "[w]ill not cause an unreasonable burden on the ability of a municipality to provide educational services"; "[w]ill not place an unreasonable burden on the ability of the local governments to provide municipal or governmental services"; "[w]ill not have an undue adverse effect on the scenic or natural beauty of the area, aesthetics, historic sites or rare and irreplaceable natural areas"; " [i]s in conformance with a duly adopted capability and development plan, and land use plan when adopted"; and "[i]s in conformance with any duly adopted local or regional plan or capital program").

123. Fla. STAT. ANN. $\$ 163.3177$ (West 2011). 
schemes, and direct appropriations. Many of these financing techniques provide support directly for local open space preservation initiatives. The Massachusetts Community Preservation Act, for example, authorizes towns and cities to establish a Community Preservation Fund by referendum. ${ }^{124}$ The fund is to be used for the preservation of open space and scenic and historic resources and for the creation of affordable housing. The referendum approves a community-wide property tax surcharge of up to three percent, and qualifies the community for state matching funds.

The Maryland Rural Legacy Program was established by the state legislature to enhance the protection of natural resources while maintaining the viability of agricultural and forest lands. ${ }^{125}$ State funds are provided to local governments and land trusts to purchase land and development rights from willing sellers. Funding sources include a portion of the state's property transfer tax, general obligation bonds, and zero-coupon bonds.

Connecticut's Protected Open Space and Watershed Land Acquisition Grant Program offers matching-fund grants to communities and nonprofit land-conservation organizations for the acquisition of open space and watershed lands. ${ }^{126}$ The State has set conservation acquisition goals for the state as a whole, and requires that when the State conveys open space lands, the recipient must execute a conservation easement limiting the land's development.

The Florida legislature has created a number of programs to preserve natural areas that are subject to development pressure. The Florida Preservation 2000 Trust Fund uses the proceeds of state revenue bonds to acquire title or development rights for open space and natural resource protection. ${ }^{127}$ The Florida Forever Program is a ten-year, $\$ 300$ million, annual, bond-funded program designed to purchase environmentally significant lands and water resource development projects. ${ }^{128}$ Bond proceeds are deposited in the Florida Forever Trust Fund, twenty-one percent of which is allocated each year to the Florida Communities Trust for

124. MASS. GEN. LAWS ANN. ch. 44B, $\$ \S 2-7$ (West 2011).

125. MD. CODE ANN., NAT. RES. \$5-9A-01 (West 2011).

126. CONN. GeN. STAT. ANN. $\$ 7-131$ d (West 2011).

127. Fla. STAT. ANN. $\$ \$ 259.101,375.045$ (West 2011).

128. Office of Greenways and Trails, FLA. DEP'T OF ENVTL. PROT., http://www.dep.state .fl.us/gwt/acq/ (last visited Feb. 28, 2012). 
grants to local governments and nonprofit environmental organizations for open space acquisition. ${ }^{129}$

Maine statutes establish the Land for Maine's Future Fund. ${ }^{130}$ The fund's revenues consist of proceeds from the sale of bonds and contributions from private and public sources to purchase lands for the conservation of biodiversity and open space. The Public Access to Maine's Water Fund is authorized to acquire lands with conservation values and also to receive monies from the Land for Maine's Future bonds. ${ }^{131}$ The state authorizes conservation easements to protect natural, scenic, or open space preservation. ${ }^{132}$ In addition, a tax reduction of twenty to thirty percent is permitted for the conservation of land defined as "open space" under a program entitled Forever Wild Open Space. ${ }^{133}$

Iowa's Resource Enhancement and Protection Act uses general legislative appropriations for wetland acquisitions. ${ }^{134}$ The Iowa legislature has authorized the use of conservation easements, strengthened their enforceability, and expanded eligible purposes of easements to include agricultural land and open space preservation. ${ }^{135}$ The Michigan Natural Resources Trust Fund Act is used in part to acquire land that is of scenic beauty or that is environmentally important. ${ }^{136}$ Rhode Island's Natural Heritage Preservation Program saves open land of scenic, natural, ecological, educational, or agricultural value. ${ }^{137}$ The fund, which receives monies from the federal government, gifts, bequests, and bond revenues, provides zero-interest loans to municipalities and conservation organizations. ${ }^{138}$

This sampling of state laws that further local open space preservation reinforces the point that a national policy for biological sequestration bolsters actions already underway in a variety of geographical locations; they are well within legal and political norms. The courts sanction laws that protect the natural

129. FLA. STAT. ANN. $\$ 259.105$ (3) (c) (West 2011).

130. ME. Rev. STAT. ANN. tit. 5, \$§6200-11 (West 2011).

131. Id. $\S \S 6203 \mathrm{~A}, 6207,6209$.

132. Id. tit. $33, \S \S 476$ to $479-\mathrm{C}$.

133. Id. tit. $36, \S 1106-\mathrm{A}$.

134. IOWA CODE ANN. $\S$ 455A.15-21 (West 2011).

135. Id. $\$ \S 457 \mathrm{~A} .1$ to -.2 .

136. MicH. СOMP. LAWS ANN. $\$ \S 324.1901-1911$ (West 2011).

137. R.I. GEN. LAWS ANN. $\$ \S 42-17.5-1$ to -6 (West 2011).

138. Id. $\$ \S 42-17.5-2$ to -3 . 
landscape, states provide financing for the same purpose, and local governments require adoption open space plans. Laws are often adopted that foster forest stewardship and agency mapping often identifies the lands that matter. These initiatives are best practices that can be identified, evaluated, and promulgated by the federal government so that they can be adapted by other states and localities to their circumstances.

\section{Local Land Use LaWS AND Programs That ENHANCE SEQUESTRATION}

When the Standard Zoning Enabling Act was promulgated and first adopted by state legislatures to encourage "the most appropriate use of the land," ${ }^{139}$ most communities simply adopted a comprehensive zoning ordinance dividing the community into use districts that separated retail, commercial, manufacturing, multi-family, and single-family uses from one another. Gradually, some communities adopted comprehensive land-use plans and then site-plan and subdivision regulations. In the 1970s, innovative land use techniques began to be used, proliferating as the growth management and then the smart growth movements crested. Today, localities are using their delegated authority to adopt a variety of supplemental regulations and, as the limits of regulation are reached, figuring out ways to acquire title or development rights to land that they do not wish to see developed. This Part discusses these traditional and neo-Euclidian techniques ${ }^{140}$ in order of their chronological development, then turns to land acquisition strategies and partnerships with land trusts; today all of these techniques are potential strategies for protecting and enhancing the sequestering environment.

139. See Standard State Zoning Enabling ACT, supra note 93 and accompanying text.

140. Separating land uses by zoning districts was declared constitutional in Euclid $v$. Ambler Really Co., 272 U.S. 365 (1926). The blueprint for development in the decades that followed was rigid and district-bound, allowing few mixed uses and little flexibility. Innovative zoning techniques such as floating zones, overlay zones, and incentive zoning appeared in more recent times and are generally referred to as "neo-Euclidian" zoning techniques. 


\section{A. Regulatory Approaches}

\section{Planning and Zoning}

It is within the legal authority of most localities to include components in their comprehensive plans that focus on naturalresource conservation and ecosystem protection. New York law allows localities to adopt comprehensive plans but does not require them to do so; nor are they required to have any particular components in their plans. For example, the zoning ordinance of the Town of La Grange, New York refers to open space provisions in its comprehensive plan and adopts a zoning ordinance intended to guide the future growth of the town and to preserve open space and other natural and historic resources of the town. ${ }^{141}$ And Buffalo's comprehensive plan even embraces climate change, pledging to "reduce greenhouse gases in order to assist in alleviating the impact of global climate change." 142

Some states, including California, require municipalities to include an open space plan or conservation element in their comprehensive plan. ${ }^{143}$ The Marin County comprehensive plan commits the county to "minimize the use of finite resources, and use all resources efficiently and effectively," and to "reduce greenhouse gas emissions that contribute to global warming." 144

Zoning ordinances can be written to protect specific areas or to protect certain characteristics of open space. For example, an area can be zoned as a recreational district. Recreational districts allow private development in the form of parks, golf courses, and other open space-friendly uses. ${ }^{145}$ Overlay zoning offers another avenue to protect open space. ${ }^{146}$ Instead of altering existing zoning districts, it merely adds a supplementary set of conditions development must also meet.147 Overlay zoning allows the community to utilize conditions not typically found in zoning

141. La Grange, N.Y., CODE $§ 240-13$ (2011).

142. City of Buffalo, Buffalo's Comprehensive Plan (2009), available at http:// www.ci.buffalo.ny.us/files/1_2_1/Mayor/COB_Comprehensive_Plan/section_245923343. html.

143. CAL. GOV'T CODE $\$ \S 65561,66563$ (2011).

144. Marin CNTy. CMTy. Dev. AGency, Marin Countywide Plan (2007), available, at http://www.co.marin.ca.us/depts/cd/main/fm/cwpdocs/CWP_CD2.pdf.

145. JOHN R. NOLON, OPEN GROUND: EFFECTIVE LOCAL STRATEGIES FOR PROTECTING NATURAL RESOURCES 108 (2003).

146. Id. at 94 .

147. Id. 
ordinances to protect natural environments, often in a manner that corresponds closely to the exact physical boundaries of the area sought to be protected. 148

In rural communities, local zoning can protect and preserve fertile agricultural soils for farming. When rural areas are close to metropolitan centers, this advances climate change mitigation by lowering energy use to transport food to urban markets. Agricultural zoning in rural communities can encourage sustainable farming practices, which can significantly increase the amount of carbon that is sequestered in farmland soils. These include using no-till farming, adding organic material to the soil, planting crops with deeper root systems, and planting cover crops. Organically managed soils can sequester up to a half ton of carbon per acre. Urban communities can encourage local food production in a number of ways, including zoning reform that allows farmers' markets, onsite food production in residential areas, and larger-scale food production, including such novel concepts as vertical farms allowed in unused or underutilized buildings.

Some municipalities adopt explicit conservation policies in their zoning ordinances. One stated purpose of the Durham County, North Carolina, zoning ordinance, for example, is to promote the health, safety, and general welfare of the residents of the county by conserving land and water resources, providing adequate light and air, and preventing overcrowding of land and undue concentrations of population. ${ }^{149}$ The zoning ordinance of Manhattan, Kansas, includes in its statement of purpose a reference to the conservation of natural resources, including open space preservation. ${ }^{150}$

Another example is the zoning ordinance of the Town of Dover, New York, which includes among its purposes the conservation of natural resources, the preservation of agricultural land and open space, growth management, and the protection of large contiguous areas of undeveloped land. ${ }^{151}$ The ordinance establishes very low-density rural and resource conservation districts, along with a variety of mixed-use districts that protect

148. Id. at 96 .

149. DuRHAM COUNTY, N.C., ZONING ORDINANCE $§ 1.1 .2$ (2011).

150. MANHATTAN, KAN., ZONING REGS. § 2-101 (2011).

151. Dover, N.Y., TOWN CODE $\$ 145-3$ (McKinney 2011). 
floodplains, stream corridors, and aquifers.

Open space and its associated natural resources and environmental functions can be protected by zoning techniques in additional ways. In Pennsylvania, the Township of West Manchester amended its single-family residential district regulations to require open space preservation in undeveloped areas. ${ }^{152}$ Before amending the ordinance, the local legislature prepared maps showing potential future development under the existing conventional zoning. This exercise, often described as a build-out analysis, illustrated the great amount of existing open space and farmland that would be lost under the present zoning ordinance. In addition, the legislature mapped anticipated open space preservation areas to show landowners and developers exactly what was envisioned: interconnected open spaces crossing parcel lines.

The Knox County, Tennessee zoning code establishes an Open Space Preservation District to provide areas in which the principal use of the land is devoted to open space or the preservation and protection of park and recreation lands, wilderness areas, beach and shoreline areas, scenic routes, wild and scenic rivers, historical and archaeological sites, watersheds and water supply areas, and wildlife and their habitats. ${ }^{153}$ Property within this district must meet criteria set out in the city's open space plan.

\section{Site Plan and Subdivision Regulations}

Even when proposed developments comply with zoning regulations, they are still subject to review and approval by a local planning board or commission that enforces site plan and subdivision regulations, which can contain rigorous provisions to protect natural resources and environmental functions on and near the affected parcels of land.

The subdivision ordinance in Grandview, Missouri, for example, contains Land Suitability Requirements and Open Space Regulations. ${ }^{154}$ The Land Suitability Requirements state that " $[\mathrm{n}] \mathrm{o}$ land shall be subdivided which is found to be unsuitable by reason of flooding, ponding, poor drainage, adverse soil conditions,

152. WEST MANChESTER, PA., ZONING ORDINANCE $\$ § 150-228.1-6$ (McKinney 2011).

153. KNOX CNTY., TENN., ZONING ORDINANCE art. V, $\$$ 5.20.01-.13 (McKinney 2011).

154. GrandVIEW, Mo., SUbDivision ORdINANCE $§ \S 27.5$-.55 (2011). 
adverse geological formation, unsatisfactory topography, or other conditions likely to be harmful to the public health, safety or general welfare." 155 This requirement establishes a development process that begins with an ecological evaluation of a site before proceeding to other development considerations. The open spaces provision of the subdivision regulations requires that anyone subdividing land set aside a specific percentage to be dedicated as open space or pay a fee. In Koncelik v. Planning Board of Town of East Hampton, ${ }^{156}$ the court upheld a planning board's conditional approval of a subdivision plat that imposed several conditions designed to protect "the extensive area of undisturbed forest, and the presence of numerous important plant species scattered throughout the site." 157

Site plan regulations are adopted to regulate the development of large land parcels that are not to be subdivided. These include, for example, the development of condominium or other commoninterest residential communities, such as planned unit developments, where the underlying land is held by the purchasers of individual housing units as tenants in common. Ninety million Americans now live in these communities and these vast acreages are regulated, by and large, by standards contained in local zoning and site plan regulations. New York statutes specifically delegate to local governments the authority to adopt site plan regulations, including standards providing for proper parking, access, landscaping, location of buildings, protection of "adjacent land uses and physical features," and "any additional elements" specified by the local legislature. ${ }^{158}$

The court in Pomona Pointe Associates v. Incorporated Village of Pomona $^{159}$ interpreted "any additional elements" to include environmental considerations. In Pomona, the plaintiff owned two lots with slopes of varying steepness. The village's steep slope law required the issuance of a special permit for the disturbance of a "very steep" or "extremely steep slope" as defined in the law. The plaintiff challenged the law, arguing that it granted authority to the planning board in excess of the authority contained in the

155. Id. $\$ 27.51$.

156. 590 N.Y.S.2d 900 (N.Y. App. Div. 1992).

157. Id. at 901 .

158. N.Y. TOWN LAW § 274-a(2) (McKinney 2011); N.Y. VILLAGE LAW § 7-725-a(2) (McKinney 2011); N.Y. GEN. CITY LAW § 27-a (2) (McKinney 2011).

159. 712 N.Y.S. 2d 275 (N.Y. Sup. Ct. 2000). 
state site plan statute. The court found that consideration of steep slope criteria was within the authority delegated to the village pursuant to the site plan review statute. It held that the protection of "adjacent land uses and physical features" authorizes the adoption of regulations to protect steep slopes. Such provisions "are directly related to the possible impact that disturbance of very/extremely steep slopes could have on water runoff and the stable, cohesive integrity of the soil, rocks, trees and vegetation on such slopes." 160 The court thought that it was clear that site plan review can include consideration of natural resource protection, especially when adjacent resources may be adversely affected.

Site plan regulations may require open spaces and green spaces of adequate proportions. In New Hampshire, local legislatures are authorized to provide for open spaces, as well as green spaces, in their site plan regulations. The site plan review statute authorizes local planning boards to provide for the harmonious and aesthetically pleasing development of the locality and its environs. ${ }^{161}$ New Jersey's site plan statute requires local governments to adopt local standards to preserve existing natural resources on the site, and to ensure adequate screening and landscaping. ${ }^{162}$

\section{a. Cluster developments.}

Normally, land is subdivided and developed in conformance with the dimensional requirements of the local zoning ordinance, which often require single family homes to be built on lots of a certain minimum size, such as one or two acres. Zoning typically requires that the entire parcel be divided into lots that conform to these minimum lot sizes and that buildings on subdivided lots conform to rigorous setback, height, and other dimensional requirements. So, for example, in a half-acre residential zone, the developer will be required to lay out lots of no less than a half-acre in size and to place homes on them that are set back by a fixed number of feet from the front, rear, and side lot lines and that are no more than thirty-five feet high.

Under cluster development, the locality permits or requires land developers to vary the dimensional requirements of zoning,

160. Id. at 278 .

161. N.H. REV. STAT. ANN. $\$ 674: 44$ (West 2011).

162. N.J. STAT. ANN. $\$ 40: 55$ D-41 (West 2011 ). 
such as lot size, setbacks, building types, and heights. This can result, for example, in homes being placed on quarter-acre lots in a half-acre zone. The land that is saved by this reconfiguration (fifty percent of it in this example) may then be left undeveloped. Often, the local homeowners' association will own and maintain this land. There is a clear connection between clustering requirements and preserving the sequestering environment on land that would otherwise be developed. Clustering encourages the preservation of wooded areas, wetlands, and previously undeveloped meadows, all of which sequester carbon, and allows for a variety of housing types, such as townhouses or other multiple dwellings.

The zoning law of North Haven, Connecticut, contains standards for development projects to qualify for a special permit for clustering. ${ }^{163}$ These include the permanent preservation of areas of ecological significance and the protection of wetlands, streams, rivers, aquifers, potential municipal water supplies, and ponds as natural resources. Cluster development may be used to "encourage innovation in land use and variety in design, layout, and type of structures constructed." 164 Among the purposes of cluster development in Lewiston, Maine, for example, is the protection of wildlife cover and other natural land features. Developers in Lewiston must consider scenic vistas, natural topography, and potential solar access when selecting building sites. ${ }^{165}$

Local laws may authorize cluster development on parcels of land of a particular size or type, and mandate minimum open space set-asides. For example, in Montgomery County, Maryland, the stated purpose of cluster development is to "provide greater flexibility in achieving a compatible mixture of agricultural and residential uses, and to protect scenic and environmentally sensitive areas without jeopardizing farming or other agricultural use [s] on a portion of the property or on adjacent or nearby properties." 166 These regulations permit development of houses that are carefully located, that are designed to reduce their perceived intensity, and that preserve agricultural lands, so long as

163. NeW HAVEN, CONN., ZONING REGS. § 2.5.1 (2011).

164. Mich. ZONing ENABling ACT, Mich. Comp. LAWS ANN. $\$ 125.3503(2)$ (Weist 2011).

165. LEWISTON, ME., CODE OF ORDS. art. XIII, $\$ 9$ (Weil 2011).

166. MONTGOMERY COUNTY, MD., ZONING ORDINANCE $§ 59-C-9.51$ (2011). 
a minimum of sixty percent of the site is protected as open space. ${ }^{167}$ Norwalk, Virginia's Conservation Development ordinance encourages clustered development that protects natural resources, including wetlands, marine and wildlife habitat, and other areas with conservation values. ${ }^{168}$

\section{b. Conservation subdivisions and low impact development.}

Conservation subdivisions also allow houses to be developed, but require more aggressive conservation practices than clustered developments, focusing on both the preserved and developed portions of the land. In areas experiencing rapid growth where thousands of acres are proposed for subdivision development, these techniques can promote practices that preserve the absorptive qualities of natural landscapes and prevent the release of stored $\mathrm{CO}_{2}$, while advancing a number of other sustainability objectives. The preservation of natural resources in subdivisions provides valuable environmental benefits in addition to carbon sequestration: wetlands and habitat preservation, stormwater management and flood prevention, watershed protection, and the prevention of erosion and sedimentation. Provisions in these regulations may encourage or require developers to plant street trees, create small parks, build vegetated green roofs, and provide landscape buffers and vegetated recreational and sitting areas or tree-lined walking and bike paths.

The emerging field of low-impact development incorporates a variety of innovative landscape and building design practices that lessen the impact of development on the environment. In more heavily urbanized areas, for example, these regulations may encourage vegetated roofs that retain rainwater, large planters on sites with capacious vegetation that serve the same purpose, or pervious surfaces and alleys that allow rainwater to percolate into the underlying soil. In both urban and suburban settings, low impact development preserves the natural environment and promotes natural drainage systems to hold stormwater and allow it to seep naturally into the ground. Low impact development standards require tree retention or planting to ensure tree canopies of up to forty percent on sites, the use of infiltration pits in lawns, the redirection of roof water into holding containers or

167. Id. \$59-C-9.52 (2011).

168. NORWALK, CONN., BLDG. ZONE REGS. art. 41, §118-410 (2011). 
onto the lawn, and the use of permeable driveways, sidewalks, and play areas.

The county code of Cherokee County, Georgia, for example, establishes conservation subdivisions to preserve open space and maintain residential density. ${ }^{169}$ The ordinance intends small residential areas to be surrounded by areas of particular aesthetic or ecological value. The ordinance also identifies rare plants and animals that are to be protected by zoning. Some of these include dwarf sumac, the freckled darter, and the amber darter, which are listed on the national endangered species list. Additionally, the ordinance purports to protect "wetlands, aquifers, topographical or soil features, marine and wildlife habitat; and other features having conservation values, including views, vistas, and indigenous vegetation."

With cluster subdivision requirements and conservation subdivision standards, small landscape gains on individual development projects can add up to significant carbon sequestration benefits, while promoting the more localized gains of cooling the urban environment, reducing the heat island effect of densely developed neighborhoods, and securing public health benefits for the urban population.

\section{Supplemental Regulations}

Beyond these traditional mechanisms for protecting open space, localities may adopt supplemental regulations that use more novel techniques to achieve that end. Chief among these for the purpose of sequestration are the adoption of timber regulations in forested communities and tree canopy or tree preservation laws in more urbanized places. Some communities award developers bonus density in exchange for protecting open space. Open space zones can be designated as "sending districts" under Transfer of Development Right laws, and protected through the transfer of building rights there to receiving zones established locally.

\section{a. Timber harvesting ordinances.}

Forested municipalities in rural areas can adopt timberharvesting ordinances regulating the environmental impacts of forestry and promoting practices that increase carbon

169. CHEROKEE CNTY, GA., ZONING ORDINANCE $§ 23.1$ (2011). 
sequestration. They may start with an inventory that identifies the qualities and characteristics of forested land. This inventory can divide forests into those that are of high timber value, high habitat value, or that are environmentally fragile because they are subject, for example, to erosion because of steep slopes or unstable soils. The municipality's comprehensive plan can have a forestry component that articulates goals, objectives, and strategies for each type of forest in the inventory. This can be translated into zoning by including best forestry stewardship practices. Effective forest management activities include harvest systems that partially maintain forest cover, minimize losses of dead organic matter, reduce soil erosion, and require planting after harvest. ${ }^{170}$

Cumberland, Maryland, has adopted a conservation zone in which the only permitted uses are agricultural, horticultural, and forestry; public and private parks; recreation areas; historic areas; conservation areas; and other similar uses. All residential uses are prohibited in this zoning district. ${ }^{171}$ Union County, Georgia, has included a Mountain Protection Plan in its zoning ordinance to protect slopes in excess of twenty-five degrees and to preserve the wildlife habitat and the aesthetics of mountainous areas, along with adjacent sensitive areas such as wetlands and floodplains. ${ }^{172}$

Forest zoning can divide privately held forests into different zones for different uses such as timber harvesting, watershed protection, wildlife habitat, or recreation. Timber zones can contain specifications for stewardship that govern private timbering practices. Specifications in a habitat forest zone concentrate on biodiversity protection, particularly for locally threatened species. Williams Township, Pennsylvania, for example, requires private forest owners to obtain a zoning permit prior to harvesting forty or more trees with a diameter of three inches or more on any tract of land larger than two acres. ${ }^{173}$ The harvester must prepare a Forestry Management Plan and an Erosion and Sedimentation Control Plan prior to obtaining a permit. ${ }^{174}$ Clear

170. Forestry: Best Management Practices in Forest Management, U. ARK. DIVISION OF AGRIC. RESEARCH \& EXTENSION, http://www.arnatural.org/forestry/bmps.htm (last visited Mar. 27, 2012).

171. Cumberland, MD., ZONING ORdinance $\$ 6.12$ (2011).

172. Union County, Ga., CODE OF ORDS. § 30-152 (2011). The entire Mountain Protection Plan spans $\$ \$ 30-151$ to -176 .

173. WILlIAMS TOWNSHIP, PA., ZONING ORDINANCE art. XIV, $\$ 1402$ (A) (19) (2011).

174. Id. 
cutting is prohibited on tracts of two acres or larger and on slopes of greater than twenty-five percent gradient. ${ }^{175}$

In the Town of Pawling, New York, a timber harvesting ordinance regulates tree clearing and harvesting to prevent erosion, sedimentation, and drainage problems. ${ }^{176}$ To clear or harvest, timber harvesters must apply for a harvesting permit that includes a sketch of the area's wetland boundaries and watercourses, a description of the proposed timber harvest, a reclamation plan, and proof of insurance. In order to obtain a permit, timber harvesters must meet detailed requirements in the review process and comply with performance standards that protect streams, prevent erosion, and minimize visual impacts. These standards are detailed both in the ordinance and a manual outlining best practices for silviculture. ${ }^{177}$

In compliance with the Forest Conservation Act of Maryland, Charles County, Maryland, adopted a Forest Conservation Ordinance, which requires developers of subdivisions greater than 40,000 square feet to submit a Forest Stand Delineation and a Forest Conservation Plan with their application for subdivisionplan approval. ${ }^{178}$ The Forest Stand Delineation must describe the proposed site's streams, soils, tree species, stand dynamics, floodplains, conservation easements, wetlands, and habitat. ${ }^{179}$ The Forest Conservation Plan must demonstrate plans to retain existing forest or else to augment or replenish diminished forests; tree protection methods to deploy during construction; and easements, deed restrictions, or covenants. ${ }^{180}$ To protect trees during construction, developers must use construction methods outlined in the Maryland Forest Conservation Technical Manual and approved by the Maryland Department of Natural Resources.

b. Tree canopy ordinances and urban forests.

Varying percentages of urban neighborhoods can be protected by tree canopies covering streets, sidewalks, private lots, parks, and other private and public lands. These trees are sometimes called

175. Id.

176. Pawling, N.Y., CODE ch. $187, \S \S 187.1$ to -14 (2011).

177. Id. § 187-9.

178. Charles CNTy., MD., Code, $\$ 298$ (2011).

179. Id.

180. Id. 
urban forests and they, of course, sequester carbon. ${ }^{181}$ Cities and villages can adopt tree canopy objectives in their comprehensive plans and dedicate themselves to increasing the percentage of the community that is shaded. In addition to sequestering carbon, urban trees provide windbreaks, reduce air conditioning costs, mitigate urban heat island effects, and make urban environments more comfortable and healthful. In heavily urbanized areas, the amount of trees and vegetation that can be preserved or added is somewhat limited but important for providing a high quality of urban life.

Maximizing urban forests in cities in the United States might increase the sequestering environment by two to three percent. ${ }^{182}$ While small, this is still of some importance. Increasing tree cover in urbanized areas from the current canopy coverage of twentyseven percent ${ }^{183}$ to thirty-two percent over the next fifty years would sequester approximately 475 million tons of $\mathrm{CO}_{2} .{ }^{184}$ This would require 704 million more trees over that time: fourteen million a year. ${ }^{185}$ There are approximately 40,000 municipalities in

181. Rowan A. Rowntree \& David J. Nowak, Quantifying the Role of Urban Forests in Removing Almospheric Carbon Dioxide, 17 J. ARBORICULTURE 269, 270 (1991) ("[T]he net amount of carbon sequestered by urban forests in the United States is estimated at about 6.5 million tons/year."). This translates into 26 million tons of $\mathrm{CO}_{2}$.

182. Hugh T. Spencer, Climate Change Mitigation Strategies for Kentucky: POLICY OPTIONS FOR CONTROLLING GREENHOUSE GAS EMISSIONS THROUGH THE YEAR 2020 AD 111 (1998), available at http://epa.gov/statelocalclimate/documents/pdf/ ky_2_fin .pdf.

183. EPA GREENHOUSE GAS INVENTORY, supra note 4, at 7-49.

184. "Total carbon storage by urban trees in the coterminous United States is estimated at 700 million tonnes." David J. Nowak \& Daniel E. Crane, Carbon Storage and Sequestration by Urban Trees in the USA, 116 ENVTL. POLLUTION 381, 387 (2002). In urban settings, EPA found that there is "an average tree canopy cover of 27 percent." EPA GREENHOUSE GAS INVENTORY, supra note 4, at 7-49. Thus, to achieve a total increase of five percent, the current urban tree canopy coverage would have to be expanded by approximately eighteen percent. Assuming the amount of carbon stored in all of this new vegetation is stored in amounts similar to the amounts of carbon stored in the existing urban trees, a five percent increase in urban tree canopy cover would store an additional $129,629,630$ tons of carbon. To reach this result, the desired increase in canopy coverage is divided by the existing canopy coverage, and then multiplied by the current carbon storage amount to calculate the amount stored in the added canopy.

Working from this projection, the amount of carbon dioxide that these additional trees would consume can also be projected. As "[c]arbon comprises 12/44 of carbon dioxide by weight," EPA GREENHOUSE GAS INVENTORY, supra note 4, at ES-3, these additional trees would have to consume at least $475,308,462$ tons of $\mathrm{CO}_{2}$ to be able to obtain the requisite amount of carbon. To reach this result, the projected carbon storage is multiplied by the inverse of the elemental carbon to carbon dioxide weight ratio.

185. "The number of trees within UAs of the United States is estimated to be 3.8 
the United States. If each community, on average, planted 350 trees each year, this goal could be reached. ${ }^{186}$ While not all localities enjoy the same amount of municipal resources or political will to expend these resources, this average number illustrates the conclusion that promoting biological sequestration through local land use policies is a viable and real arrow in society's quiver in the fight against climate change.

Land use regulations and project approvals can be used to preserve urban trees. The zoning regulations of the Town of Wallingford, Connecticut, for example, require "that existing trees ... be preserved to the maximum extent possible." 187 Under those regulations, trees and landscaping are to be preserved and provided to reduce excessive heat, glare, and accumulation of dust; to provide privacy from noise and visual intrusion; and to prevent the erosion of the soil, excessive runoff of drainage water, and the consequent depletion of the groundwater table and the pollution of water bodies.

In Santa Monica, California, one of the purposes of the zoning regulation is to protect and enhance the quality of the natural and built environment and to ensure adequate public open space. ${ }^{188}$ Development in each of the city's zoning districts is subject to certain environmental standards. These standards include maximum unit density, lot coverage, minimum lot size, setback requirements, and building spacing, as well as a requirement for open space.

Some state statutes expressly permit local planning boards to require the dedication of parklands or to collect a fee in lieu of such dedication. ${ }^{189}$ Portland, Oregon's city council approved a fee schedule for new residential development that assesses park development charges ranging from $\$ 4500$ for a single room occupancy unit to over $\$ 8000$ for a single family home. Some states

billion." JOHN F. DWYer et AL., CONNECTING PEOPLe WITH ECOSYSTEMS IN THE $21 \mathrm{ST}$ CENTURY: AN ASSESSMENT OF OUR NATION'S URBAN FORESTS 32 (2000). If 3.8 billion trees result in a $27 \%$ tree canopy cover, then an additional 704 million trees would constitute a $5 \%$ increase in tree canopy coverage. That would require 14 million trees added per year for 50 years.

186. If 40,000 municipalities, then 350 trees per year per municipality for fifty straight years.

187. TOWN OF WALLINGFORd, CONN., ZONING CODE $§ 7.2$ (E) (2011).

188. CiTY OF SANTA MONICA, Cal., ZONING ORDINANCE $\$ 9.04 .02 .020$ (b), (d) (2011).

189. CONN. GEN. STAT. ANN. \$ 8-25 (a) (West 2011); Nev. REv. STAT. ANN. \$ 278.4979 (West 2011); N.C. Gen. STAT. ANN. \$ 160A-372 (West 2011). 
allow their local governments to require parkland dedication or set-asides as part of the subdivision-approval process. ${ }^{190}$ Some state statutes are silent or vague regarding the matter. ${ }^{191}$ A few states expressly prohibit as confiscatory the dedication of land or fees to achieve open space objectives. ${ }^{192}$

In New York, state statutes authorize planning boards to ensure that the recreational needs of the occupants of residential subdivisions and site plans are met by requiring land to be set aside where a municipal study shows that there is now, or will be, an unmet need for recreational facilities in the municipality. ${ }^{193}$ The planning board may require a financial contribution in lieu of a land reservation only where it specifically determines that, in a particular case, the land subject to subdivision review is not of sufficient size or adequate character to create a suitable recreational area for the subdivision's occupants.

\section{c. Density bonuses.}

Many states provide density bonuses, additional dwelling units, or commercial space beyond that allowed in a zoning district, to developers who provide public benefits in their projects including the provision of open space. Some state laws allow "cash award" alternatives to density bonuses, where the cash received can be used to purchase development rights to offsite open space areas, including the acquisition of conservation easements over such land.

The Lancaster County, Nebraska, zoning resolution allows development under an approach it calls the Community Unit Plan. ${ }^{194}$ This plan includes bonuses for developments that preserve the rural character of the site, natural habitats, natural environmental features, and existing drainage courses. Developers may receive density bonuses of up to twenty percent for conserving energy, protecting environmentally sensitive areas, and for maintaining agricultural lands. A proposed zoning ordinance of Gallatin County, Montana, would provide density bonus incentives

190. MONT. CODE ANN. $\$ 76-3-621$ (West 2011).

191. Fl.A. STAT. ANN. $\S 163.3161$ (3) (West 2011); IND. CODE ANN. $\S \S 36-7-4-700$ to -712 (West 2011).

192. MASS. GEN. LAWS ANn. ch. $41, \S 81 \mathrm{Q}$ (West 2011).

193. N.Y. GEN. CITY LAW $§ 33(4)$ (2011); N.Y. TOWN LAW $\$ 277(4)$ (McKinney 2011); N.Y. VILLAGE LAW $\$ 7-730$ (4) (McKinney 2011).

194. LANCASTER CNTY., NEB., ZONING REGS. $\$ 14.003$ (McKinney 2011). 
if the developer conserves a specified amount of open space. ${ }^{195}$ To obtain the density bonus, a developer would formally apply by submitting a site plan indicating the location and amount of open space conserved, its existing vegetation, wildlife, and riparian areas, property lines, topographic information, and other site characteristics. The planning staff would then decide if the proposed development meets the county's requirements.

Under an open space incentive program adopted by New Berlin, Wisconsin, conservation subdivisions that preserve open space are eligible for a density enhancement. ${ }^{196}$ The local planning board is authorized to provide $10 \%$ more lots to a development where $55 \%$ of the parcel of is dedicated to open space, a density enhancement of $10 \%$ more than the usual zoning limit. A $60 \%$ dedication of open space allows for a $20 \%$ density enhancement. Similarly, in Suffolk, Virginia, a density bonus is awarded for the redevelopment of existing strip centers, provision of public parks, open space, agricultural and critical area preservation, as well as for the development of retirement housing, traditional neighborhoods, and clusters or hamlets. ${ }^{197}$ An incentive zoning point table is used to determine the maximum number of development points that may be awarded for a given category.

In Milton, Florida, increased height and floor area are granted in exchange for the provision of public access along a development's waterfront, for pedestrian-oriented features, public recreational and entertainment features, onsite parking screened from public view, creative open space landscaping with perpetual maintenance, energy conservation measures, underground utilities, and screening of all utilities. ${ }^{198}$ In Lakewood, Colorado, a density bonus is granted in exchange for: increased usable open space, enhancing landscaping and ground cover, improved visual impact, increased plant materials, and any design feature that significantly improves the quality of the living environment. ${ }^{199}$

195. Gallatin CNTY., MONT., CODE Sec. 3 , § 11.11.1.3 (2011), available at http://www.gallatin.mt.gov/public_documents/gallatincomt_plandept/uploadedpdfs/dr aft_article.III.ag-160.zoning.district.pdf.

196. City Of New Berlin, Wis., City Code ch. 275, art. IV, § 275-33(I) (McKinney 2011).

197. CITY OF SUFfolK, VA., CODE OF ORDS. $§ 31-409$ (McKinney 2011).

198. CITY OF MiLTON, FLA., CODE OF ORdS. art. III, $\S 12.5$ (McKinney 2011).

199. City of Lakewood, Colo., CODE $\$ 17-6-4$ (24) (McKinney 2011). 
d. Transfer of development rights.

Where authorized by state law, localities can provide for the transfer of the right to develop property under current zoning provisions from one part of the community to another. This technique, called Transfer of Development Rights or TDR, is often used to preserve critical environmental areas, farms and forests, or valuable open spaces. A 1997 survey of 3500 local governments and a review of planning literature found 107 TDR programs in twentyfive states. TDR programs have been established in rural communities as well as large cities, including New York and Chicago. ${ }^{200}$

There are three basic elements to a TDR program: the sending district, the receiving district, and the TDR credits themselves. ${ }^{201}$ The sending district consists of the area to be protected from development. ${ }^{202}$ The receiving district is located where additional density can be absorbed and supported with existing or expanded infrastructure and services. ${ }^{203}$ The TDR credits are a legal representation of the abstract development rights that will be severed from property in the sending district and grafted onto property in the receiving district. ${ }^{204}$ The TDR credits are usually traded in a free market, although a TDR bank may be established to facilitate exchanges. ${ }^{205}$ When a TDR credit is purchased from a property owner in the sending district, that property owner records a deed restriction prohibiting development on the property. ${ }^{206}$ The TDR credit can then be applied to property in the receiving district as a density bonus. ${ }^{207}$

TDR is one of a few land use techniques that is capable of making a basic adjustment in a community's large-scale pattern of land development. In Chesterfield Township, New Jersey, for example, the TDR ordinance allows for the shifting of development pressure from the township's agricultural,

200. John R. Nolon \& Victoria L. Polidoro, Examining TDR in New York: Why Isn'l It Working? What Are the Obstacles? Can They Be Overcome?, N.Y. ZONING LAW AND PRACTICE REPORT (2006).

201. Patricia Salkin, American Law OF ZONING $\$ 34: 12$ (5th ed. 2011 ).

202. $I d$.

203. Id.

204. Id.

205. Id.

206. Id.

207. Id. 
environmentally sensitive, or open space areas to neighborhoods designated for growth. The program allows the township to maintain its rural character while encouraging planned development and minimizing potential conflicts between farmers and nonfarming neighbors. Chesterfield's development rights are traded through a Transfer of Development Rights Bank, which is run by the New Jersey State Agriculture Development Committee. This type of intergovernmental support is often needed from regional, state, or federal agencies to provide local TDR initiatives the type of technical competence, scale of operations, and resources they need to be successful.

\section{B. Land Acquisition}

There are federal limitations to local control of private development in the interest of promoting sequestration. Strategies that prohibit development of vulnerable lands may run afoul of constitutional protections recognized by the United States Supreme Court under the Takings Clause of the Fifth Amendment, incorporated under the Fourteenth Amendment. ${ }^{208}$ As such, owners must be left with some economic value under prevailing land use regulations. In the interests of protecting the sequestering landscape, local regulations should avoid preventing all development of the land. The Supreme Court has said that in the "extraordinary circumstance when no productive or economically beneficial use of land is permitted, it is less realistic to indulge our usual assumption that the legislature is simply adjusting the benefits and burdens of economic life." 209

The regulations discussed above, for the most part, permit some gainful development of each parcel of land. As a result, when they are challenged as regulatory takings they are not reviewed under the standards of Lucas, but rather under the standards established in another seminal Supreme Court case, Penn Central

208. See U.S. CONST. amend. V ("No person . . . shall be compelled in any criminal case to be a witness against himself, nor be deprived of life, liberty, or property, without due process of law; nor shall private property be taken for public use, without just compensation.").

209. Lucas v. S.C. Coastal Council, 505 U.S. 1003, 1017-18 (1992) (quoting Penn Central Transp. Co. v. City of New York, 438 U.S. 104, 124 (1978)). In Lucas, a regulation that prohibited all economic development of the land was deemed to be a total taking requiring, in most instances, the regulator to provide just compensation to the regulated party. 505 U.S. at 1003. 
Transportation Co. v. City of New York. ${ }^{210}$ Generally applicable regulations such as subdivision and site plan regulations, under Penn Central, are presumed to be constitutional, and the challenger has a heavy burden of proving that they constitute a regulatory taking. ${ }^{211}$ The Court, under Penn Central, looks at three factors: the economic impact of the regulation on the claimant, the extent to which the regulation has interfered with distinct investmentbacked expectations, and the character of the governmental regulation. ${ }^{212}$ As the consequences to the public of climate change become more and more evident, the character of regulations intended to promote sequestration will be an important positive factor in determining their validity under the Takings Clause.

Regardless of whether regulations promoting sequestration are vulnerable to challenge under the Takings Clause, aggressive regulation may not be the preferred way to preserve sequestering resources for a variety of reasons grounded in science, politics, or fairness. In such cases, the local government has the option of acquiring title, development rights, or conservation easements to valuable lands. ${ }^{213}$

Assuming that the requisite public need can be shown, government agencies may exercise their powers of eminent domain to acquire land for public recreation or natural resource preservation. ${ }^{214}$ Colorado statutes, for example, authorize any town

210. 438 U.S. 104 (1978).

211. See id. at 130-32.

212. Id. at 124 .

213. Hooper Brooks, Foreword to JOHN R. NOLON, OpEN Ground: EFFECTIVE LOCAL Strategies for Protecting Natural Resources ix, x (2003) ("Open Space Law embodies nonregulatory strategies including the acquisition of title to environmentally sensitive land or the imposition of conservations easements on them. Beginning in the late 1990 s, environmental advocates successfully lobbied state and local governments to appropriate or bond funding for open space acquisition. Regional and local land trusts have acquired significant funding for the same purpose and, in addition to acquiring title and easements, have secured voluntary contributions of larid or restrictive covenants that preserve critical environmental functions of strategically located lands.").

214. See, e.g., Perati v. United States, 352 F.2d 788 (9th Cir. 1965) (upholding condemnation of land for inclusion in Yosemite National Park); Pastan v. City of Melrose, 601 F. Supp. 201 (D. Mass. 1985) (holding that the taking of land by a town for the purpose of creating a public park was constitutionally acceptable, even where the ulterior motive of the town was to block condominium development); United States v. 0.16 of an Acre of Land, More or Less, Situated in Suffolk, N.Y., 517 F. Supp. 1115 (E.D.N.Y. 1981) (holding that condemning a subdivided parcel within the boundaries of Fire Island National Seashore by the Secretary of the Interior was authorized by Fire Island National Seashore Act, one purpose of which is to conserve and preserve relatively unspoiled 
to acquire land or an interest in land in order to preserve open space, sites, and vistas of recreational, historic, aesthetic, or other public interest. ${ }^{215}$ Given the political unpopularity of condemnation, government agencies will, in most instances, attempt to acquire land through voluntary agreement with the owners. Colorado provides incentives in the form of tax credits to encourage private owners to donate their property to a governmental entity or nonprofit organization.

\section{Local Financing Sources}

There are several methods that local governments use to raise the funds needed for land acquisition. The following illustrate various approaches taken when such actions are authorized by state law:

- Annual appropriations: "Localities may appropriate revenues derived from local property taxes to acquire interests in open lands as part of the local budgeting process." 216

- Multi-year appropriations: "Municipalities may ask their voters to approve a multi-year appropriation of a specified increase in the local property tax rate for the purpose of acquiring interests." 217

- Bonds: "Municipal bonds may be issued and the proceeds used for the acquisition of interests in open lands." The issuance of municipal bonds may be subject to a referendum requirement or the local legislature itself may take the initiative to place the bond resolution on the ballot. ${ }^{218}$

- Real estate transfer tax: State legislatures may authorize local government to impose a tax on the transfer of title to real property within the local jurisdiction. Authorization for

beaches and dunes for the use of future generations).

215. Colo. ReV. STAT. ANN. \$31-25-301 (West 2011).

216. Jefrrey Lejava, Open Lands ACQuistion: Local Financing Techniques UNDER NEW YORK LAW 2 (2000) (prepared in collaboration with the Town of Warwick, Orange County, N.Y.).

217. Id.

218. See Williams, supra note 19 , at 12 ("Despite the weak economy and pervasive talk of less government and lower taxes, voters in the 2010 elections passed 83 percent of the ballot initiatives presented nation-wide to fund land and water conservation."). 
this tax may be subject to referendum. ${ }^{219}$

- Reduced tax assessment: "Local governments may lease development rights from the owners in exchange for a reduction in property tax assessments during the lease's term." A landowner may agree to a limited-term lease of the land's development rights, a conservation easement for that term may be imposed on the land for that term, and during that term a reduced tax assessment may applied lowering the taxes that must be paid by the owner. ${ }^{220}$

- Cash in exchange for density bonuses: In states where localities may offer density bonuses to developers in exchange for cash, these funds can be used for acquisition purposes. 221

- Land trust funds: Some localities work in partnership with land trusts whose funds can be used for acquisition.

\section{Purchase of Development Rights}

When local governments have available financial resources, they may establish a Purchase of Development Rights program under which they buy the development rights on lands that sequester carbon. This has the effect of preventing development that would result in the loss of the stored carbon that comes from soil disturbance, clear cutting, or other interruption of the organic sequestration process associated with land development. In order for this to work, the value of the development rights under current zoning and land use regulations must be calculated. These development rights may be severed from the ownership of the underlying title to the land. Such development rights may then be sold to the local government or to a land trust or other appropriate entity and held in trust to ensure that the land is not further developed. This option leaves the title to the land in the hands of private owners who continue to pay property taxes but only on the value of the land as affected by the extinction of the development rights. The result is similar to that of purchasing an

219. LEJAVA, supra note 216 , at 3.

220. Id. at'3-4.

221. See, e.g., TOWN OF WaRwICk, N.Y., CoDE $\S 164-47.6$ (McKinney 2011). See generally NOLON, supra at note 145, at 557 (exploring the basic principles of density incentives and illustrating several examples of localities that have adopted such ordinances). 
easement that precludes certain types of development that adversely affect the environment.

\section{Conservation Easements}

A conservation easement is a legal agreement between a property owner and a local government, land trust, or other qualified private organization or governmental unit. Its purpose is to preserve the property's natural resource or other public values inherent in the land. The easement operates like a restrictive covenant burdening the use of the owner's land. The covenant is enforceable by the local government, land trust, or other qualified organization. The effect of a conservation easement is to limit activities on land that compromise conservation values or environmental functions, including carbon sequestration. The terms of the agreement vary depending upon the nature of the property, the desires of the owner, and the interest of the organization that will hold the easement.

Arizona statutes authorize conservation easements for the purpose of preserving historical, architectural, archaeological, or cultural aspects of real property, or for open space and wildlife preservation. ${ }^{222}$ In Texas, through statutorily authorized conservation easements, more than 13 million private acres are managed under Parks and Wildlife Department wildlife management plans that emphasize an ecosystem approach to conservation. 223

The State of New York also authorizes the use of conservation easements. ${ }^{224}$ In Smith v. Town of Mendon, New York's highest court held that a conservation restriction imposed as a condition to site plan approval is not an exaction and is not subject to heightened judicial scrutiny when challenged as a regulatory taking. ${ }^{225}$ Prior to this challenge, the Planning Board of the Town of Mendon, New York, had conditioned the site plan approval for a single-family home development on the owner's acceptance of a conservation easement on environmentally sensitive areas of the property. The

222. ARIZ. REv. STAT. ANN. §§ 33-271 to -276 (2011).

223. TEX. NAT. RES. CODE ANN. $\$ \$ 183.001$ to -.006 (West 2011); Texas Biodiversily Laws \& Regulations, A NATURAL History OF NORTH CENTRAL TEXAS, http://www.nhnct.org/urban/biodivlaws.html (last visited Mar. 27, 2012).

224. N.Y. TOWN LaW § 261-a (McKinney 2011).

225. Smith v. Town of Mendon, 822 N.E.2d 1214 (N.Y. 2004). 
town had established four overlay districts that cover sensitive lands that contain steep slopes or border on major creeks, wooded areas, or floodplains. The overlay district provisions prohibit development and other land disturbing activities unless the landowner can show that a proposed activity will not adversely affect the protected resources. The town's zoning code designated the owner's parcel as part of an environmental overlay district subject to special development requirements. ${ }^{226}$ To ensure that these restrictions were enforced and to give notice to future owners of the parcel, the local approval board required the imposition of a conservation easement on the land.

\section{Working with Land Trusts}

To improve the protection of open lands, local governments can partner with land trusts to identify land with important ecosystem services to conserve and to ensure that protections placed on land are permanent. ${ }^{227}$ Through these partnerships, land trusts can participate in local open space planning to ensure that local governments identify critical environmental areas for preservation. This helps secure the designation of proper land for preservation in comprehensive plans, zoning, and land use approvals. Further, local land use boards can partner with land trusts when they require the creation and recording of conservation easements when imposing conservation conditions on building projects. Land trusts can hold and manage such easements, ensuring that environmental conditions placed on development are monitored and enforced over time. Additionally, the recorded easement notifies future purchasers of the restrictions during the title search stage of the real estate transaction, and such arrangements prevent the local land use board from undoing an easement.

In Wisconsin, more than fifty land trusts protect over 100,000 acres of land within the state. The Gathering Waters Conservancy is an umbrella organization that assists the state's land trusts and communities in preserving land and water resources. The Town of Dunn, in Dane County, Wisconsin, has implemented land

226. TOWN OF MENDON, N.Y., ZONING, ch. 200, art. VI, § 200-21 (2011).

227. See generally BRADFORD S. Gentri ET AL., YAle SCH. OF ForeStRY \& ENVTL. StUdies, RePort No. 27, Optimizing Prrvate Land Conservation and PUblic LAND USE Planning/Regulation (2011). 
preservation efforts for more than twenty-five years, and in 1997, working with the Dane County Natural Heritage Land Trust, initiated the first purchase of development rights project for land conservation in Wisconsin. ${ }^{228}$ The ordinance creating the town's Land Trust Commission and Rural Preservation Program states that the commission "shall maintain contact with public and private agencies to maximize the resources and coordinate efforts to preserve the rural character of the town." 229 At least one of the seven-member commission must be a representative of a county nonprofit conservation organization. The ordinance authorizes the town's board of supervisors to preserve land through the purchase of conservation easements, purchase of title, payments to nonprofit organizations, and voluntary conveyances. The town's program has protected more than 1700 acres of land.

Land trusts are beginning to recognize the importance of carbon sequestration. Some simply attribute a value to sequestration as beneficial and thus worthy of investment. Land trusts like the World Land Trust ${ }^{230}$ and the Pacific Forest Trust ${ }^{231}$ have adopted this approach. Others use detailed sequestration metrics in analyzing the purchase of a property or the creation of an easement. ${ }^{232}$ The terms of acquisition used by these trusts dictate how forests that are acquired or put under conservation easements are managed in order to ensure they act as effective

228. TOWn OF DUnN, WiS., ORdinance No. 4-3 (2011).

229. Id. at No. 4-3(II) (B) (1).

230. Renton Righelato, Climate Change and Nature Conserzation, WORLD LAND TRUST, http://www.worldlandtrust.org/about/climate-change-policy.htm (last visited Feb. 7, 2012).

231. E-mail from Anton Chiono, Policy Analyst, The Pac. Forest Trust, to John R. Nolon, James D. Hopkins Professor of Law, Pace Univ. Sch. of Law (June 2, 2011, 16:15 EST) (on file with author) ("Currently, sequestration potential is not a major criterion in [The Pacific Forest Trust's] evaluation of either the priority of a particular conservation project or its financing prospects via future carbon revenues. In [The Pacific Forest Trust's] calculus, carbon sequestration potential is a consideration inasmuch as it might provide another marginal income source to a landowner. Where this potential exists, [the Trust] would tout it as another benefit to the landowner if they do indeed opt to conserve their land-and then [the Trust] would likely help them actually develop the carbon project down the road. However, [sequestration potential is not] currently a guiding consideration-and certainly not to the point that [the Trust] ha[s] developed detailed sequestration metrics to aid the decision process.").

232. E-mail from Don Morrow, Dir. of Projects, The Trust for Public Land, to John R. Nolon, James D. Hopkins Professor of Law, Pace Univ. Sch. of Law (May 31, 2011, 04:58 EST) (on file with author) (stating “[T]he Trust for Public Land, The Nature Conservancy and the Conservation Fund . . . are doing projects that are specifically funded in whole or in part by carbon sequestration payments"). 
carbon sinks. These include The Conservation Fund (TCF) and The Nature Conservancy (TNC). TCF's North Cóast Forest Conservation Initiative was designed to utilize the sale of carbon offsets to make sustainable management practical. ${ }^{233}$ TCF is the landowner and has purchased over 40,000 acres as a part of this initiative. ${ }^{234}$

\section{OpEn SPACE LAW REVISITED: TOWARD A NATIONAL BIOLOGICAL SEQUESTRATION STRATEGY 235}

This Article began with the optimistic notion that technologies exist that can stabilize carbon emissions and significantly mitigate climate change if they are properly deployed. ${ }^{236}$ It demonstrates that biological sequestration is a powerful method of offsetting carbon emissions ${ }^{237}$ and traces the evolution of open space law, showing that it can enhance biological sequestration. ${ }^{238}$ It concludes by promoting a national strategy for enhancing biological sequestration, building on accepted open space preservation practices at the state and local level.

There is a critical role for the federal government to play in advancing biological sequestration, adding its weight and resources to those of the states and local governments described in Parts IV and V. ${ }^{239}$ To be done cost efficiently, the sequestering landscape must be measured and analyzed at the national level by the federal government, which can then provide data on priority areas for sequestration as well as technical and financial support that state and local governments need to supplement their existing

233. Becky Ham, What Is Climale Change?, THE CONSERVATION Fund, http:// www.conservationfund.org/climate_change (last visited Feb. 3, 2012).

234. Id.

235. The author thanks Dexter H. Locke, Master of Environmental Science Candidate, Yale School of Forestry and Environmental Studies, for his assistance in identifying and analyzing the sources discussed in this section.

236. See Pacala \& Socolow, supra note 2, and accompanying text.

237. See EPA GREENHOUSE GAS INVENTORY, supra note 4, at 65.

238. See Working Group III, IPCC, Climate Change 2007: Mrtigation (Bert Metz et al. eds., 2007).

239. See Thinking Ecologically, supra note 75 , at 10 ("John Turner and Jason Rylander of the Conservation Fund criticize the disconnect between environmental policy, largely set at the state or federal level, and local land use decision-making. They point out that environmental policy-makers have acted as though these two realms of decisionmaking were entirely unconnected. Because the cumulative effect of local land use decisions is the prime determinant of environmental quality, they argue that we must identify new ways to link up local, state, and federal decision-making."). 
open space preservation strategies. In urban areas, this work must focus on the expansion of urban tree canopies, which carry benefits beyond sequestration, ${ }^{240}$ and in rural areas, on the preservation and expansion of those landscapes in which most of the nation's sequestration takes place. ${ }^{241}$

\section{A. Measurements}

The federal government can embrace, and improve on, current technologies to determine what types of vegetative landscapes are responsible for the eighteen percent of carbon dioxide that is captured by sequestration, identify where they are located and where they can be expanded, and target priority areas for enhanced sequestration. The technology for measuring the vegetated environment has recently improved and has become a useful tool for land use planning. ${ }^{242}$ In urban settings, the technology has been used effectively in several cities. ${ }^{243}$ The

240. The greening of cities is essential if they are to become attractive and hospital places to live as the American population increases. To the extent that cities attract this new population, they will further mitigate carbon emissions, energy consumption, potable water use, and water pollution.

241. See EPA GREENHOUSE GAS INVENTORY, supra note 4. As evidence that a national sequestration policy can be effective, see the New Zealand Emission Trading Scheme, under which owners of forested land receive trading credits, each one of which is equal to one ton of $\mathrm{CO}_{2}$ and tradable within the Kyoto Protocol. Among the features of the program, owners of certain forested lands can receive one credit for post-1990 increases in forested area. Participants submit maps of carbon accounting areas on their property to the Ministry of Agriculture and Forestry demonstrating these increases. It is this national agency that uses its geospatial mapping system to instruct participants how to calculate these increases; once submitted and confirmed, the Ministry allocates trading units to the participant's account. See N.Z. MINISTRY OF AGRIC. AND FORESTRY, INTRODUCTION TO FORESTRY IN THE EMISSIONS TRADING SYSTEM (2011).

242. Light Detection and Ranging (LiDAR) is a relatively new technique that emits a laser in the near infrared portion of the electromagnetic spectrum (so that it is not visible). LiDAR makes identifying where existing trees are and could be in urban areas easier and more accurate. See JARLATH O'NEIL-DUNNE, SPATIAL ANALYSIS LAB., UNIV. OF VT., A Report on the City of PHILAdelphia's Existing and Possible Tree Canopy (2011), available at http://www.fs.fed.us/nrs/utc/reports/UTC_Report_Philadelphia.pdf (providing an illustrative example of a tree canopy report); see also Dexter $\mathrm{H}$. Locke et al., Prioritizing Preferable Localions for Increasing Urban Tree Canopy in New York Cily, 3 CITIES AND THE ENVIRONMENT 1 (2010), available at http://nrs.fs.fed.us/pubs/37293 (discussing how such a report can be used for local tree canopy planning).

243. For example, reports indicate that in New York City in 2007 there were 5.2 million trees containing 1.35 million tons (valued at $\$ 24.9$ million) of carbon, and that sequester 42,300 tons per year (worth $\$ 779,000$ per year). DAVID J. NOWAK ET AL., U.S. DEP'T OF AGRIC., ASSESSING URBAN FOREST EFFECTS AND VALUES: NEW YORK CITY'S URBAN FOREST 1 (2007), available at http://www.nrs.fs.fed.us/pubs/rb/rb_nrs009.pdf. Similar 
undeveloped nature of rural areas makes it relatively easy for this measurement technology to identify the forests, meadows, and pastures that should be enhanced through proper stewardship and protected from development in appropriate ways.

The cost of providing vegetative cover studies to interested states and localities is not exorbitant, particularly in light of the need for providing these governments with the beginning metrics they need to build strategies and measure progress.

\section{B. Strategies}

The national biological sequestration policy can promulgate and promote best practices, such as model state laws that delegate authority to local governments to adopt effective local regulations. It can identify and distribute components of model comprehensive plans for promoting sequestration and explain how localities have successfully used techniques such as urban forest canopy plans, tree preservation ordinances, conservation easements, transfer of development rights, and the other initiatives discussed above.

\section{Incentives}

Federal sequestration planning and implementation grants can be allocated to promote demonstration projects, including funds for evaluating strategies to determine how much sequestration is achieved. With these measurements, a broader strategy can be developed that pays state and local governments on a per ton basis for the carbon they sequester. The owners of private land can be encouraged to cooperate through offers to pay them for imposing conservation easements on their land that require the maintenance and stewardship of sequestering lands. Other federal programs, such as the Wetland Reserve Program, the tax deductibility of donated conservation easements, and other agricultural and urban grant programs, can be used to enhance sequestration.

reports have been done in other urban areas. See DAVID J. NOWAK \& ERIC J. GREENFIELD, U.S. DEP'T OF AGRIC., URBAN AND COMMUNITY FORESTS OF NEW ENGLAND: CONNEGTICUT, MAINE, MASSACHUSETTS, N̦EW HAMPSHIRE, RHODE ISLAND, VERMONT (2008), available at http://nrs.fs.fed.us/pubs/gtr/gtr_nrs38.pdf; DAVID J. NOWAK ET AL., U.S. DEP'T OF AGRIC., ASSESSING URBAN FOREST EFFECTS AND VALUES: PHILADELPHIA'S URBAN FOREST (2007), available al http://nrs.fs.fed.us/pubs/rb/rb_nrs007.pdf; DAVID J. NOWAK ET AL., U.S. DEP'T OF AGRIC., ASSESSING URBAN FOREST EFFECTS AND VALUES: WASHINGTON, D.C.'S URBAN FOREST (2006), available at http://nrs.fs.fed.us/ pubs/rb/nrs_rb001.pdf. 
As the consequences of climate change become more observable on the ground, there will be strong support for adaptive strategies that can be guided and assisted by the federal government. Efforts are already beginning in cities and developed suburbs to increase tree canopies; to require vegetation on roofs, planters, sidewalks, streets, and parks; and to promote urban gardening, among countless other initiatives that help developed communities adapt to climate change. The practice is far enough advanced that best practices exist, case studies are being written, and the efficacy of further action is understood. ${ }^{244}$

The critical issue in urban settlements is how to make them more attractive to the 100 million new Americans who must be settled on the land in ways that minimize their carbon emissions. ${ }^{245}$ Chief among strategies to make urban places livable in an era of warmer temperatures is to increase vegetation to cool, soothe, and refresh life in denser, mixed-use neighborhoods served by transit. This is a critical adaptive strategy, and one that will become an imperative as the consequences of climate change become harsher. Cities and developed suburbs should be guided by metrics provided by the federal government, informed by best practices, and qualify for federal assistance.

How much is it worth financially to reduce carbon dioxide in the atmosphere by the one gigaton that the natural environment sequesters each year? This is the amount of carbon dioxide emissions attributable to over 50 million Americans. ${ }^{246}$ A national

244. Patricia E. Salkin, Sustainability and Land Use Planning: Greening Slate and Local Land Use Plans and Regulations to Address Climale Change Challenges and Preserve Resources for Future Generations, 34 WM. \& MARY ENVTL. L. \& POL'Y REV. 121, 165 (2009) (quoting How to Conserve Water and Use it Effectively, U.S. EPA, http://www.epa.gov/owow/NPS/ chap3.html (last visited Mar. 3, 2012)) ("Xeriscaping is one popular water conservation program employed throughout the country. Xeriscaping is a holistic approach to landscape design that uses planning and design, selection of appropriate plant species, water efficient irrigation techniques, and other sustainable practices to make landscaping more sustainable. Specific benefits include reduced water use, decreased energy use (less pumping and treatment required), reduced heating and cooling costs because of carefully placed trees, decreased storm water and irrigation runoff, fewer yard wastes, increased habitat for plants and animals, and lower labor and maintenance costs.") (internal quotation marks omitted).

245. U.S. CENSUS BUREAU, supra note 64; Nolon, The Land Use Slabilizalion Wedge Strategy, supra note 1 , at nn.15-42.

246. The U.S population was $308,745,538$ as of the 2010 Census. 2010 Census Data, U.S. CENSUS BUREAU, available at http://2010.census.gov/2010census/data/ (last visited Mar. 3, 2012). Additionally, 5505.2 $\mathrm{Tg} \mathrm{CO}_{2}$ is equal to $5.5052 \mathrm{Gt} \mathrm{CO}_{2}$, as $1 \mathrm{Gt}$ is equal to $1000 \mathrm{Tg}$. By dividing the net U.S. $\mathrm{CO}_{2}$ emissions (in Gt) from the total U.S. population, a 
program that results in a clearer understanding of the role of the sequestering environment in climate management and that initiates an effective program for measuring, preserving, and expanding biological sequestration is a worthy initiative to support with the investment of funds that will inevitably become available for emission reductions. ${ }^{247}$ Meanwhile, federal spending programs that promote the quality of urban life and preservation of natural resources must prioritize initiatives that promote sequestration and the resiliency of human settlements.

rough estimate of the amount of people attributable to $1 \mathrm{Gt}$ of $\mathrm{CO}_{2}$ can be made: $308,745,538$ population/5.5052 $\mathrm{Gt}=56,083,000$ people per $\mathrm{Gt}_{\mathrm{CO}}$ (approximately).

247. Hayes \& Beauvais, supra note 59 , at 696 (asserting that biological sequestration "ought to be included in a cost-effective portfolio of compliance strategies if and when the United States chooses to implement a domestic GHG reduction program") (citation omitted). 
Notes 
